medRxiv preprint doi: https://doi.org/10.1101/2021.05.30.21257971; this version posted July 15, 2021. The copyright holder for this preprint

(which was not certified by peer review) is the author/funder, who has granted medRxiv a license to display the preprint in perpetuity.

All rights reserved. No reuse allowed without permission.

\title{
Heterologous ChAdOx1 nCoV-19 and BNT162b2 prime-boost vaccination elicits potent neutralizing antibody responses and $\mathrm{T}$ cell reactivity
}

Rüdiger Groß ${ }^{\mathrm{a}^{*}}$, Michelle Zanoni ${ }^{\mathrm{a}^{*}}$, Alina Seide ${ }^{\mathrm{a}^{*}}$, Carina Conzelmann ${ }^{\mathrm{a}}$, Andrea Gilg , Daniela $^{\mathrm{a}}$ Krnavek $^{\mathrm{a}}$, Sümeyye Erdemci-Evin ${ }^{\mathrm{a}}$, Benjamin Mayer ${ }^{\mathrm{b}}$, Markus Hoffmann ${ }^{\mathrm{c}, \mathrm{d}}$, Stefan Pöhlmann ${ }^{\mathrm{c}, \mathrm{d}}$, Alexandra Beil ${ }^{\mathrm{e}}$, Joris Kroschele ${ }^{\mathrm{e}}$, Bernd Jahrsdörfer ${ }^{\mathrm{f}, \mathrm{g}}$, Hubert Schrezenmeier ${ }^{\mathrm{f}, \mathrm{g}}$, Frank

Kirchhoff $^{\mathrm{a}}$, Jan Münch ${ }^{\mathrm{a}, \mathrm{h}}$, Janis A. Müller ${ }^{\mathrm{a}, \#}$

${ }^{a}$ Institute of Molecular Virology, Ulm University Medical Center, 89081 Ulm, Germany

${ }^{\mathrm{b}}$ Institute for Epidemiology and Medical Biometry, Ulm University, Ulm, Germany

${ }^{\mathrm{c}}$ Infection Biology Unit, German Primate Center - Leibniz Institute for Primate Research, Göttingen, Germany

${ }^{\mathrm{d}}$ Faculty of Biology and Psychology, Georg-August-University Göttingen, Göttingen, Germany

${ }^{\text {e }}$ Central Department for Clinical Chemistry, University Hospital Ulm, 89081 Ulm, Germany

${ }^{\mathrm{f}}$ Institute for Transfusion Medicine, Ulm University, $89081 \mathrm{Ulm}$, Germany

${ }^{\mathrm{g}}$ Institute for Clinical Transfusion Medicine and Immunogenetics Ulm, German Red Cross

Blood Services Baden-Württemberg-Hessen and University Hospital Ulm, 89081 Ulm, Germany

${ }^{\mathrm{h}}$ Core Facility Functional Peptidomics, Ulm University Medical Center, 89081 Ulm, Germany

*authors contributed equally

\# Correspondence: Janis A. Müller (Janis.mueller@uni-ulm.de), Institute of Molecular Virology, Ulm University Medical Center, 89081 Ulm, Germany; phone: +49 73150065170 
medRxiv preprint doi: https://doi.org/10.1101/2021.05.30.21257971; this version posted July 15, 2021. The copyright holder for this preprint (which was not certified by peer review) is the author/funder, who has granted medRxiv a license to display the preprint in perpetuity.

All rights reserved. No reuse allowed without permission.

\begin{abstract}
Heterologous COVID-19 vaccination regimens combining vector- and mRNA-based vaccines are already administered, but data on solicited adverse reactions, immunological responses and elicited protection are limited. We aimed to evaluate the reactogenicity, humoral and cellular immune responses towards different SARS-CoV-2 variants after a heterologous ChAdOx1 nCoV-19 BNT162b2 prime-boost vaccination and analyzed a cohort of 26 individuals aged 25-46 (median 30.5) years that received a ChAdOx1 nCoV-19 prime followed by a BNT162b2 boost after an 8week interval. Self-reported solicited symptoms after ChAdOx $1 \mathrm{nCoV}-19$ prime were in line with previous reports and less severe after the BNT162b2 boost. Antibody titers increased significantly over time resulting in strong neutralization titers two weeks after the BNT162b2 boost. Neutralizing activity against the prevalent strain B.1.1.7 (Alpha) and immune-evading VOC B.1.351 (Beta) was 4-fold higher than in individuals receiving homologous BNT162b2 vaccination. No difference was seen in neutralization of VOI B.1.617 (Kappa). In addition, the heterologous vaccination induced CD4+ and CD8+ T cells reactive to SARS-CoV-2 spike peptides of all analyzed variants; Wuhan-Hu-1, B.1.1.7, B.1.351, and P.1 (Gamma). In conclusion, heterologous ChAdOx1 nCoV-19 / BNT162b2 prime-boost vaccination regimen is not associated with serious adverse events and results in a potent humoral immune response and elicits $\mathrm{T}$ cell reactivity. Variants B.1.1.7, B.1.351 and B.1.617.1 are potently neutralized by sera of all participants and reactive $\mathrm{T}$ cells recognize spike peptides of all tested variants. These results suggest that this heterologous vaccination regimen is at least as immunogenic and protective as homologous vaccinations.
\end{abstract}


medRxiv preprint doi: https://doi.org/10.1101/2021.05.30.21257971; this version posted July 15, 2021. The copyright holder for this preprint (which was not certified by peer review) is the author/funder, who has granted medRxiv a license to display the preprint in perpetuity.

All rights reserved. No reuse allowed without permission.

\section{Introduction}

The first cases of the coronavirus disease 2019 (COVID-19) were reported to the World Health Organization on December $31^{\text {st }} 2019$ (1), and within 93 days the causative severe acute respiratory syndrome coronavirus 2 (SARS-CoV-2) had infected over 1 million people worldwide (2). Only 250 days later, the first person received a COVID-19 vaccine outside a clinical trial, and vaccinations are now considered a key strategy for ending the pandemic(3). Approved vaccines include the adenovirus-based ChAdOx1 nCoV-19 (Vaxzevria, AstraZeneca) and mRNA-based BNT162b2 (Comirnaty, BioNTech/Pfizer), which induce humoral and cellular immunological responses $(4-8)$, showed high efficacy in clinical trials $(9,10)$ and a high degree of protection from COVID-19 in real-world settings $(11,12)$. However, the occurrence of rare thrombotic events with thrombocytopenia after $\mathrm{ChAdOx} 1 \mathrm{nCoV}-19$ vaccinations, especially in individuals younger than 60 years, associated with the generation of auto-platelet factor 4 antibodies, halted vaccination of this group with ChAdOx1 nCoV-19 in some countries (13-15). As a consequence, several public health agencies now recommend that boost vaccination of individuals already primed with ChAdOx1 nCoV-19 is carried out in a heterologous regimen with an mRNA vaccine (16). In others, it is not applied due to limited data on safety and immunologic responses elicited by such a regimen. Two recent studies and preprints indicate that such a heterologous schedule is associated with more severe (17) or similar (18-20) solicited symptoms, respectively. Similarly, one published article and upcoming preprints suggest that robust immune responses are elicited (18-22), but there is limited knowledge about $\mathrm{T}$ cell responses or protection against the variants of concern (VOC) by heterologous vaccination regimens $(20,22)$. Here, we studied a cohort of 26 individuals (16 female, 10 male; median age 30.5, range 25-46) (Table 1) who received ChAdOx1 nCoV-19 prime and, due to changing recommendations in Germany, (16) a BNT162b2 boost vaccination with a 56 day interval and evaluated solicited adverse reactions, humoral and cellular immune responses against several spike variants.

\section{Table 1 Study participants:}

\begin{tabular}{|l|l|l|l|}
\hline & Total & $\mathbf{m}$ & $\mathbf{f}$ \\
\hline Participants & 26 & 10 & 16 \\
\hline Age median & $30.5(25-46)$ & $32(25-46)$ & $30.5(26-44)$ \\
\hline Prior SARS-CoV-2 infection & 1 & 0 & 1 \\
\hline $\begin{array}{l}\text { Platelet factor 4 autoantibodies } \\
\text { (determined in (47)) }\end{array}$ & 0 & 0 & 0 \\
\hline
\end{tabular}


medRxiv preprint doi: https://doi.org/10.1101/2021.05.30.21257971; this version posted July 15, 2021. The copyright holder for this preprint (which was not certified by peer review) is the author/funder, who has granted medRxiv a license to display the preprint in perpetuity.

\section{Results}

Reactogenicity following prime and boost vaccination was evaluated by all study participants by self-reporting of solicited local and systemic symptoms according to a standardized questionnaire. Symptom severity (mild, moderate, severe) and duration ( $<1 \mathrm{~h}$, few $\mathrm{h}, \sim 1 \mathrm{day},>1$ day) is reported for each individual participant (Figure S1A) and percentage of participants (Figure 1A,B).

Both, prime and boost vaccination, induced mild to moderate solicited adverse reactions in most participants with $88.4 \%$ (23/26) reporting at least one mild or moderate symptom following prime; $23 / 26(88.4 \%)$ and $21 / 26(80.8 \%)$ reporting at least one mild or moderate symptom following boost vaccination (Figure 1A,B). Most common symptoms after prime vaccination with ChAdOx1 nCoV-19 were pain at the injection site $(92.3 \%)$, fatigue $(80.8 \%)$, headache $(73.1 \%)$, chills $(61.5 \%)$, myalgia (61.5\%) and fever (61.5\%). Following boost vaccination with BNT162b2, most participants again reported pain at the injection site $(84.6 \%)$ and fatigue $(84.6 \%)$, but chills (19.2\%), myalgia (38.5) and fever (19.2\%) were less common. $23 \%$ of participants $(6 / 26)$ reported at least one severe symptom following prime, $15.4 \%(4 / 26)$ after boost. Fatigue $(7.7 \%)$ and headache (15.4\% for prime, $3.8 \%$ for boost) were amongst symptoms reported as severe for both doses, while myalgia was reported as severe by $11.5 \%$ of participants following prime, but none after boost.

Comparing cumulative solicited adverse reaction (cSAR) scores, reactogenicity following prime with ChAdOx1 nCoV-19 was significantly $(\mathrm{p}=0.008)$ higher than following boost with BNT162b2 (cSAR score median 11 and 6 respectively, Figure 1C). Individually, most participants $(19 / 26,73.07 \%)$ had milder reaction to boost compared to prime. 6/26 (23.07\%) of participants described more severe reactions to boost vaccination (Figure S1B). A trend towards higher cSAR scores reported by female participants was seen for both boost and prime vaccinations (Figure 1D,E). No correlation was observed between reactogenicity and age (Figure S1C,D). Individual reactogenicity towards prime and boost vaccination showed a weak but significant correlation (Figure 1F, $\mathrm{p}=0.039$ ). 
medRxiv preprint doi: https://doi.org/10.1101/2021.05.30.21257971; this version posted July 15, 2021. The copyright holder for this preprint (which was not certified by peer review) is the author/funder, who has granted medRxiv a license to display the preprint in perpetuity. All rights reserved. No reuse allowed without permission.

Mild $\square$ Moderate $\square$ Severe

A
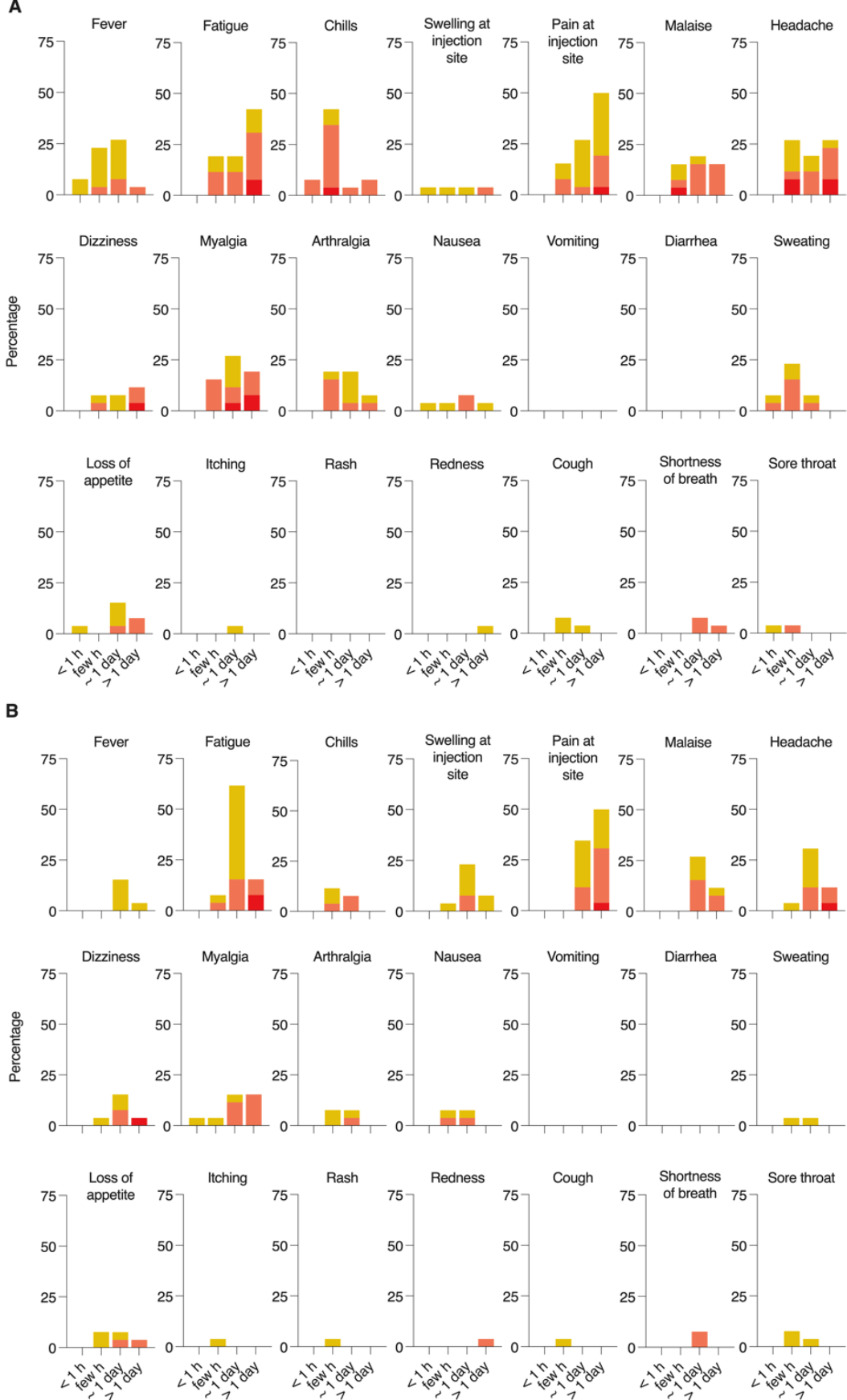

C

D

E

F
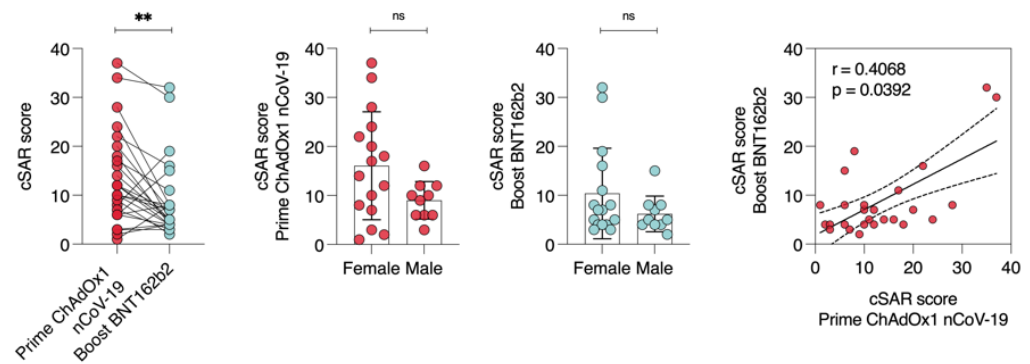
medRxiv preprint doi: https://doi.org/10.1101/2021.05.30.21257971; this version posted July 15, 2021. The copyright holder for this preprint (which was not certified by peer review) is the author/funder, who has granted medRxiv a license to display the preprint in perpetuity.

All rights reserved. No reuse allowed without permission.

Fig. 1. Solicited adverse reactions following ChAdOx1 nCoV-19 prime and BNT162b2 boost vaccination. Percentages of participants with individual symptoms following prime (A) or boost (B) vaccination. Severity is graded on a scale of 1-2 (for some symptoms) or 1-3 (for most), according to Common Terminology Criteria for Adverse Events (US Department of Health and Human Services, Version 4.03) (23). (C) Cumulative solicited adverse reaction (cSAR) scores of all participants following prime and boost vaccination. For calculation of cSAR scores, symptom gradings are summed and an additional score point is added for symptoms lasting more than $24 \mathrm{~h}$. Analysis of cSAR scores by (D, E) participant gender, and (F) comparison between cSAR scores following prime and boost vaccination. The SARS-CoV-2 convalescent individual was excluded in all statistical analyses. Paired t-test; ns not significant; $* * \mathrm{p}<0.01$

We collected sera from participants 2 days (-2) or on the same day (0) before vaccination, and at days 15 - 16, 30 - 37, and 53 - 57 after ChAdOx1 nCoV-19 prime, and days 6 - 11 and $14-19$ after BNT162b2 boost (64 - 65 or $72-73$ after prime, respectively) to determine antibody responses (Figure 2). Already 15-16 days after prime, 19/25 (76\%) participants showed detectable anti-SARS-CoV-2-spike-IgG levels and 17/25 (65\%) detectable IgA levels (Figure 2A,B). IgG levels peaked after 30 - 37 days and were detectable in 24/25 (96\%) participants. Until days 53 57 , IgG levels slightly decreased, consistent with previous results after single ChAdOx $1 \mathrm{nCoV}-19$ dose $(5,6)$. IgA values were highest already at days 15-16 and became undetectable in $24(92 \%)$ participants at days 53 - 57. Notably, only 6 - 11 days after the BNT162b2 boost, IgG was detectable in all (100\%) and IgA in $23(92 \%)$ of 25 participants. Until day 14-19 after boost (7273 post $\mathrm{ChAdOx} 1 \mathrm{nCoV}-19), \mathrm{IgG}$ and IgA were detectable in all participants. This corresponds to an at least 3.7-fold increase in median IgG levels from pre-boost to 2 weeks post-boost. We next quantified cumulative anti-SARS-CoV-2-spike-IgM and $\mathrm{IgG}$ concentrations and detected median antibody levels of 3.39 (range 0-2,126) units per $\mathrm{ml}(\mathrm{U} / \mathrm{ml})$ 15-16 days after prime vaccination in $22 / 25(88 \%$ ) participants (Figure 2C). From days $30-37$ on, IgM and IgG were detected in all participants and medians continuously increased to $28(1.86-1,436)$ and $63.9(4.27-1,005) \mathrm{U} / \mathrm{ml}$ after days 30 - 37 or 53 - 57, respectively. After BNT162b2 boost, titers increased 134-fold to $8,614(126-24,831)$ at days 6 - 11 and 135-fold to 8,815 (1,206-19,046) 14 - 19 days after the second dose. Strikingly, the resulting titers were 8.1-fold higher than those determined for sera obtained after 13-15 days of a homologous BNT162b2 boost (individuals with median age 41 (2555); median titers 1,086; range 498-3,660; Appendix Table 1). Cumulative IgM/G titers correlated with IgG titers at each timepoint analyzed post prime (Figure S2, Appendix Table 2).

Sera were also evaluated for their potential to inhibit SARS-CoV-2-spike-receptor binding domain/ACE2 interaction using a surrogate virus neutralization test (sVNT) (Figure 2D). 15-16 days after ChAdOx1 nCoV-19 administration 13/25 (52\%) participant sera showed ACE2 neutralizing activity, correlating significantly with IgG and IgM/G titers (Figure S2, Appendix Table 2). Median neutralization activity of the positive sera was $46 \%$ (range $32-97 \%$ ). Until days 53-57, the number of participants with neutralizing sera increased to 19/26 (73\%) and the median ACE2 neutralization to $62 \%$ (range 32-95\%), again in correlation with $\mathrm{IgG}$ and $\mathrm{IgM} / \mathrm{G}$ values (Figure S2, Appendix Table 2). After BNT162b2 boost, all participants showed potent neutralization with a median of $97 \%$ (range 32-98\%) after 6-11, and 98\% (range 89-98\%) after 1416 days suggesting a strong and functional antibody response after heterologous vaccination in all participants. 
medRxiv preprint doi: https://doi.org/10.1101/2021.05.30.21257971; this version posted July 15, 2021. The copyright holder for this preprint (which was not certified by peer review) is the author/funder, who has granted medRxiv a license to display the preprint in perpetuity. All rights reserved. No reuse allowed without permission.

The potency of neutralizing activity was further quantified using vesicular stomatitis virus (VSV)based pseudoviruses carrying the SARS-CoV-2 spike protein of the most prevalent SARS-CoV-2 B.1.1.7 (Alpha) variant. This system faithfully recapitulates SARS-CoV-2 entry into cells and its inhibition(24-26). 15-16 days after ChAdOx1 nCoV-19 prime, neutralizing titers ranging from $36-906$ were detectable in $8 / 25(32 \%)$ participants (Figure 2E). The number of participants with detectable neutralization increased to maximum in 12/25 (48\%) individuals at days 30-37 with a median neutralization titer of 74 (range 20-552) in responders, which slightly decreased until days 53-58. Two weeks after the BNT162b2 boost, neutralizing titers were detected in all participants with a median titer of 2,744 (range 209-8,985). Of note, while for some individuals the titers further increased from week 1 to week 2 after BNT162b2 boost, other individuals plateaued at titers > 1,000 (Figure S3). At all time points, neutralizing activity correlated with IgG or IgM/G titers (Figure S2, Appendix Table 2). Remarkably, the median titer of these individuals was 3.9-fold higher than the median titer of 14 individuals vaccinated with BNT162b2 in a homologous regimen (709; range 305-1,806) suggesting a stronger humoral protection after a heterologous vaccination. Of note, a SARS-CoV-2 convalescent individual (triangle symbol) showed a strong response after the first dose in all assays, high $\operatorname{IgG}, \operatorname{IgA}$ or $\operatorname{IgM} / \mathrm{G}$ values, most effective ACE2- neutralization and a high neutralization titer of 90615 - 16 days after prime that decreased over the days to 201 at day 53-57 (Figure 2A-E).

Additionally, we evaluated the neutralizing activities of sera obtained 2 weeks post full vaccination against the immune evading variants B.1.351 (Beta) and B.1.617.1 (Kappa). Pseudovirus entry driven by B.1.351 spike was neutralized with 2-fold lower potency ( $\mathrm{p}<0.05)$ compared to B.1.1.7 spike. However, it was still entirely blocked at higher doses with a median titer of 1,297 (range 252 - 6,523). Neutralization of the B.1.617.1 spike was not reduced compared to B.1.1.7 spike (median titer of 1,309; range $150-13,252$ ) (Figure 2F). Sera of individuals vaccinated with homologous BNT162b2 showed lower neutralizing titers against all spike variants tested (Figure $2 \mathrm{~F}$ ), suggesting stronger humoral protection after a heterologous vaccination also against VOCs. Notably, no correlation of neutralizing antibody titre (PVNT50) with sex or age was observed for either cohort (Figure S4). 
A

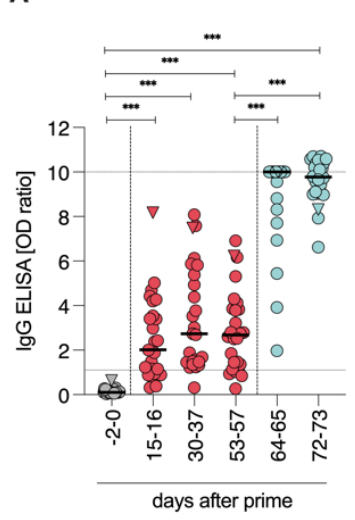

D

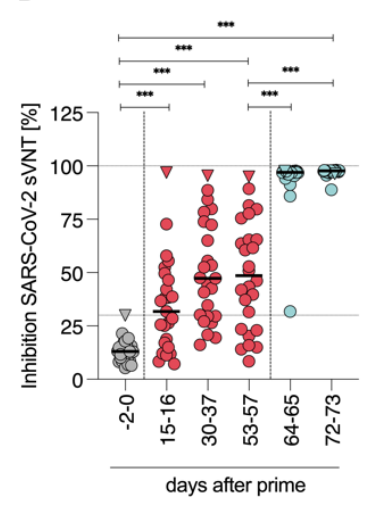

B

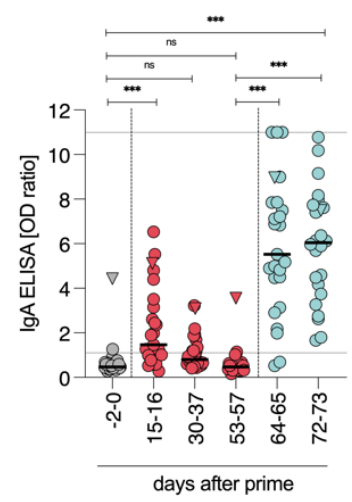

E

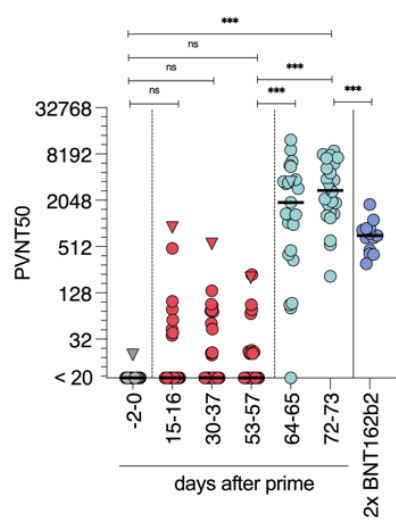

C

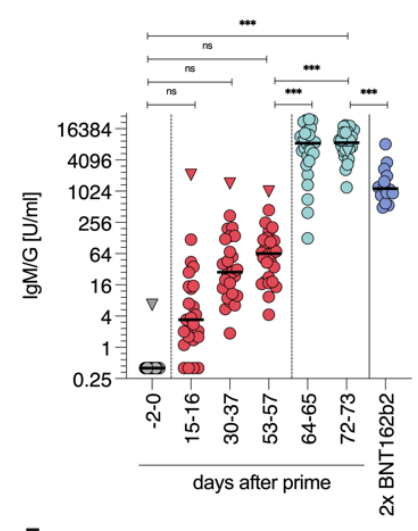

$\mathbf{F}$

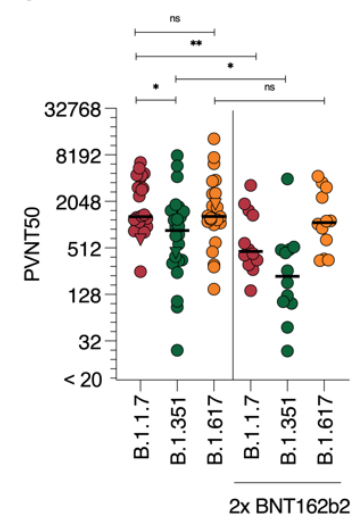

Fig. 2. Humoral response. Quantification of anti-SARS-CoV-2 S1 spike domain (A) IgG and (B) IgA titers. (C) Quantification of anti-SARS-CoV-2 spike IgG and IgM responses as units per ml (U/ml) by immunoassay. (D) SARS-CoV-2 surrogate virus ACE2 neutralization test. (E) VSVbased B.1.1.7 SARS-CoV-2 spike pseudovirus neutralization assay. (F) VSV-based B.1.1.7, B.1.351 and B.1.617.1-SARS-CoV-2 spike pseudovirus neutralization assay. Titers expressed as serum dilution resulting in 50\% pseudovirus neutralization (PVNT50). Triangle indicates SARSCoV-2 convalescent individual, who was excluded from all statistical analyses. Grey symbols indicate datapoints pre-vaccination, red datapoints indicate datapoints after prime and light-blue after boost vaccination. Dark-blue indicates samples of participants with homologous BNT162b2 prime-boost regimen. Dashed horizontal lines indicate upper and lower limit of detection/cut-off, respectively. Dashed vertical lines indicate prime and boost vaccination. Longitudinal antibody measurements were analyzed by means of a mixed linear regression model. Mann-Whitney-U test compares ChAdOx1 nCoV-19 and BNT162b2 titers *** $\mathrm{p}<0.0001, * * \mathrm{p}<0.001, * \mathrm{p}<0.05$, ns not significant

To evaluate cellular immunity, we isolated peripheral blood mononuclear cells from blood samples provided by $21 / 26$ participants before ChAdOx $1 \mathrm{nCoV}-19$ prime, and 6-11 days post BNT162b2 boost and 14-19 days post boost (72-73 days post prime), considered as full vaccination according to the vaccination schedule. Cells were exposed to SARS-CoV-2 spike-spanning peptide-pools and analyzed for intracellular cytokines TNF $\alpha$, IFN $\gamma$, and IL-2 to determine spike-specific CD4 ${ }^{+}$ and $\mathrm{CD}^{+} \mathrm{T}$ cell responses (Figure 3, S5, S6). 6-11 days after boost, 45-65\% of participants already showed IFNy, TNF $\alpha$, or IL-2 producing $\mathrm{CD}^{+}{ }^{+} \mathrm{T}$ cells upon stimulation with Wuhan-Hu-1 SARS$\mathrm{CoV}-2$ spike peptides (Figure $3 \mathrm{~A}$ ). After full vaccination, $\mathrm{CD}^{+} \mathrm{T}$ cells producing IFN $\gamma$ (median 
medRxiv preprint doi: https://doi.org/10.1101/2021.05.30.21257971; this version posted July 15, 2021. The copyright holder for this preprint (which was not certified by peer review) is the author/funder, who has granted medRxiv a license to display the preprint in perpetuity.

0.055, range 0.018-0.168), IL-2 (median 0.055, range $0-0.134$ ) or TNF $\alpha$ (median 0.057; range 0.01 - 0.193) were significantly increased upon stimulation as compared to the pre-vaccination baseline. Spike reactive $\mathrm{CD}^{+}{ }^{+} \mathrm{T}$ cells were detected in $63-95 \%$ suggesting that most individuals developed a robust spike-specific $\mathrm{T}$ helper 1 (TH1) $\mathrm{CD}^{+} \mathrm{T}$ cell response post BNT162b2 boost. In addition, we observed an increase of spike-specific $\mathrm{CD}^{+} \mathrm{T}$ cells predominantly producing IFN $\gamma$ (median 0.092, range 0-0.665) and TNFa (median 0.055, range $0-0.375$ ) compared to prevaccination baseline samples in all previously uninfected participants (Figure 3A). Levels of spikespecific $\mathrm{CD}^{+} \mathrm{T}$ cells producing IL-2 (median 0.01, range 0-0.052) were lower, which is in agreement with responses after homologous BNT162b2 vaccination (7). We then compared the response to SARS-CoV-2 spike variants B.1.1.7, B.1.351, and P.1 (Gamma) at day 6-11 after boost, and found that both $\mathrm{CD}^{+}$and $\mathrm{CD}^{+} \mathrm{T}$ cells showed IFN $\gamma$ responses to all spike variants (Figure 3B), however less pronounced for TNF $\alpha$ and IL-2 (Figure S6 C,D). CD4 ${ }^{+} \mathrm{T}$ cell reactivity towards B.1.351 spike was slightly decreased and $\mathrm{CD}^{+} \mathrm{T}$ cell reactivity towards B.1.1.7 spike was slightly elevated, but overall a robust cellular immune response against all three spike variants was found in most participants. Of note, reactivity of the $\mathrm{CD}^{+}$and $\mathrm{CD}^{+} \mathrm{T}$ cells of the convalescent individual did not increase after vaccination (Figure 3A), indicating pre-existing cellular immunity. Overall, these findings show a robust humoral and cellular immune response after heterologous vaccination. 

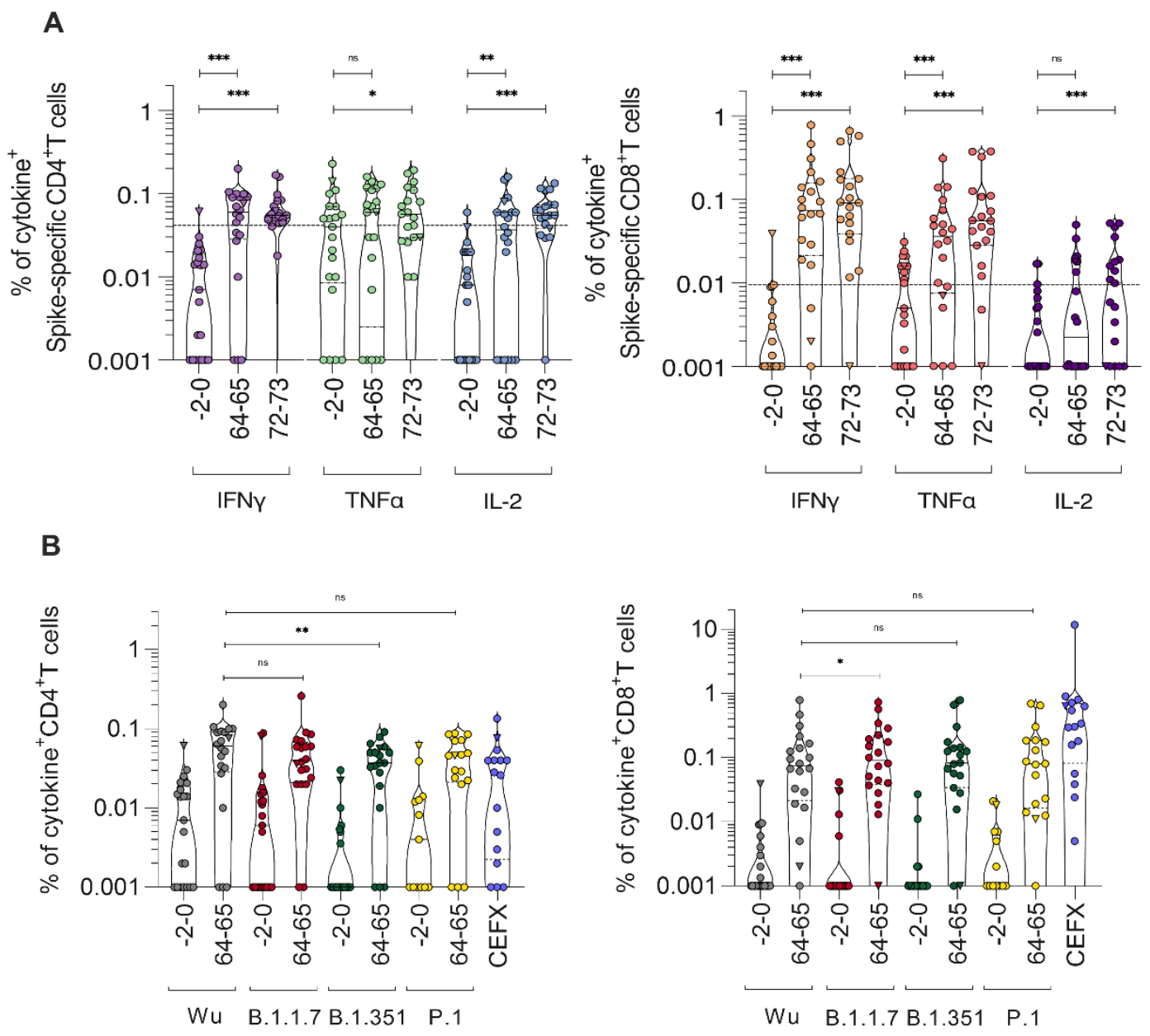

Fig. 3. SARS-CoV-2 spike-specific $\mathrm{CD4}^{+}$and $\mathrm{CD8}^{+} \mathbf{T}$ cell responses. PBMCs from day $-0-2$ pre- and day 64-65 or 72-73 post prime vaccination (1-2 weeks post boost) of study participants were stimulated with (A) SARS-CoV-2 Wuhan-Hu-1 spike peptide-pool and cytokine production determined by flow cytometry. (B) PBMCs from day -0-2 pre and day 64-65 post prime were stimulated with SARS-CoV-2 spike peptide pools derived from B.1.1.7, B.1.351, or P.1. or of epitopes of different infectious agents (CEFX) and compared with Wuhan-Hu-1 from (A). Cytokine $^{+} \mathrm{T}$ cells were background-corrected for unstimulated cells. Values lower than median plus one standard deviation of pre-vaccination (0.04\% for CD4, 0.01\% for CD8) were considered negative. Triangle symbol indicates SARS-CoV-2 convalescent individual, where cytokine release was already high in absence of stimulation. Wilcoxon matched-pairs signed rank test compares cytokine-positive cells before and after vaccination (1-2 weeks post-boost) or upon stimulation with different SARS-CoV-2 spike variants, $* * * p<0.0001, * \mathrm{p}<0.05$. 
medRxiv preprint doi: https://doi.org/10.1101/2021.05.30.21257971; this version posted July 15, 2021. The copyright holder for this preprint (which was not certified by peer review) is the author/funder, who has granted medRxiv a license to display the preprint in perpetuity.

All rights reserved. No reuse allowed without permission.

\section{Discussion}

Based on the regulatory approvals for ChAdOx1 nCoV-19 and mRNA vaccines, the interval between prime and boost vaccinations ranges between 4 -12 weeks (27-29). For ChAdOx1 nCoV19, a 12 week interval has been shown to result in stronger immune responses (30), most likely because the immunity against the vector wanes. Accordingly, e.g. in Germany heterologous vaccinations are currently typically performed after 12 weeks. Existing vector immunity, however, is irrelevant in the context of a mRNA boost vaccination, on which basis our cohort received the boost after 8 weeks. This heterologous ChAdOx 1 nCoV-19/BNT162b2 vaccination elicited strong $\mathrm{IgM} / \mathrm{G}$ and $\operatorname{IgA}$ responses, neutralizing activities and $\mathrm{T}$ cell responses in all previously uninfected participants, while solicited adverse reactions to vaccination were as expected for a prime ChAdOx1 nCoV-19 vaccination and reduced following heterologous BNT162b2 boost.

A previous study showed that a heterologous vaccination schedule with 4-week interval results in stronger reactogenicity after boost (17), whereas a published and a pre-printed studies with an 8to 12-week interval did not confirm this effect (18-20). We did not directly compare different vaccination schemes. Thus, we cannot draw definitive conclusions on differences, which might also depend on cohort age (6). With an 8-week interval, we observed an overall milder reactogenicity following heterologous boost with $\mathrm{BNT} 162 \mathrm{~b} 2$ than after initial prime vaccination with ChAdOx $1 \mathrm{nCoV}-19$ and no serious adverse events, arguing for the safety of this regimen in young adults.

Our immunological data suggest that a heterologous vector-based/mRNA prime-boost schedule is highly effective in preventing COVID-19, as neutralizing antibody levels correlate with immune protection from symptomatic SARS-CoV-2 infection (31) and $\mathrm{CD}^{+} \mathrm{T}$ cell responses have been associated with a mild disease course $(32,33)$. Endpoint neutralizing antibody titers determined 2 weeks post boost were slightly higher than those detected upon homologous BNT162b2 vaccinations (Figure $2 \mathrm{C}, \mathrm{E}$ ). This is in agreement with results from pre-printed studies (20-22) and suggests that ChAdOx1 nCoV-19 / BNT162b2 prime-boost vaccination elicits potent immune responses $(18,19)$. However, results might also be influenced by the young cohort age. Factors contributing to this high degree of immunogenicity might be the circumvention of vector immunity. The BNT162b2 encoded spike sequence contains a two-proline mutation not present in ChAdOx1 nCoV-19, which fix spike in a pre-fusion confirmation (10, 34). It is tempting to speculate that altered spike conformations between the vaccinations may be beneficial for effective neutralizing responses.

Neutralizing activity towards VOC B.1.351, previously reported to show partial evasion of vaccination-induced antibodies $(24,35,36)$, was slightly decreased compared to B.1.1.7 following heterologous vaccination, again in agreement with recently pre-printed data (22). However, the titer was still higher than for B.1.1.7 after two doses of BNT162b2. Neutralization of emerging B.1.617.1, which appears to be the most efficiently neutralization-evading strain of the B.1.617 lineage(37), was not reduced compared to B.1.1.7. Whether these immunological findings translate into effective general protection from VOCs in real-life setting remains to be determined, however neutralizing antibody titers have been described to be a good predictor of protective vaccine efficacy (31) and the substantial neutralization capacity against the most prevalent and evading virus variants is encouraging. 
medRxiv preprint doi: https://doi.org/10.1101/2021.05.30.21257971; this version posted July 15, 2021. The copyright holder for this preprint (which was not certified by peer review) is the author/funder, who has granted medRxiv a license to display the preprint in perpetuity.

All rights reserved. No reuse allowed without permission.

Secretory IgA responses at the mucosal site of SARS-CoV-2 entry are of particular interest with regard to prevention of virus transmission and (re-)infection (38). We detected a general increase in serum $\operatorname{IgA}$ levels with strong variation between participants, suggesting mucosal protection shortly after vaccination. However, IgA levels decreased over time after prime vaccination, and future studies, especially assessing IgA and secretory IgA levels and persistence at mucosal entry sites after boost are warranted.

In almost all participants SARS-CoV-2 specific $\mathrm{CD} 8^{+}$or $\mathrm{CD} 4^{+} \mathrm{T}$ cells were detected 2 weeks after full vaccination. These effects were similar to those reported after a single ChAdOx $1 \mathrm{nCoV}-19$ dose and after homologous BNT162b2 vaccination $(5,7)$. This suggests that $\mathrm{T}$ cell responses are similarly effective after heterologous vaccination. Importantly, $\mathrm{T}$ cell reactivity was potent against most prevalent VOC B.1.1.7 and most humoral immunity-evading VOCs B.1.351 and P.1. This is in line with previous findings that variants escaping humoral immunity are still recognized by reactive $\mathrm{T}$ cells indicating broad protection from SARS-CoV-2 on a cellular level $(10,39)$, also after heterologous vaccination.

In line with previous results, in an individual participant who was previously tested SARS-CoV-2 positive, a single prime vaccination dose already elicited strong antibody responses $(40,41)$. In this case, the observed neutralizing titers 2 weeks after prime were as high as the median titer of those receiving the homologous BNT162b2 vaccination. However, titers (IgM/G) further increased 8-fold after boost, suggesting that prime-boost might provide more potent and longer lasting protection also in convalescent patients.

In conclusion, heterologous vaccination schedule of ChAdOx1 nCov-19 prime, followed by BNT162b2 boost after 8 weeks for participants with a median age of 30.5 years was, within our cohort, tolerable and effective. This regimen provides flexibility for future vaccination strategies and will be useful for vaccine schedules during shortages. The perspective that heterologous vaccination might be superior to homologous regimens should be considered as a potential strategy to elicit particularly strong immune responses e.g. in immunocompromised, highly exposed individuals or against VOCs in future prime-boost vaccinations and vaccine updates against COVID-19. Similarly, whether other vector- or mRNA-based vaccine combinations or those based on other technologies are as effective needs to be addressed in future studies. 
medRxiv preprint doi: https://doi.org/10.1101/2021.05.30.21257971; this version posted July 15, 2021. The copyright holder for this preprint

(which was not certified by peer review) is the author/funder, who has granted medRxiv a license to display the preprint in perpetuity.

All rights reserved. No reuse allowed without permission.

\title{
Materials and Methods
}

\author{
Study Design \\ A cohort of 26 individuals aged 25-46 (median 30.5) years that received a ChAdOx1 nCoV-19 \\ prime followed by a BNT162b2 boost after an 8-week interval were analyzed for reactogenicity, \\ antibody responses and $\mathrm{T}$ cell reactivity. Participants were enrolled prior to initial vaccination \\ and initial samples taken up to 2 days before prime vaccination. Solicited adverse reactions after \\ both prime and boost vaccination were self-reported and ranked by severity and duration. Blood \\ samples were taken from all participants at several time points throughout the study and analyzed \\ for antibodies and T-cell reactivity against SARS-CoV-2 spike.
}

\section{Collection of serum and PBMC samples}

Blood samples from individuals were obtained after recruitment of participants and written informed consent as approved by the ethics committee of Ulm university (99/21). Participants received a heterologous vaccination regimen because after their ChAdOx1 nCoV-19 prime vaccination, the German Standing Committee on Vaccination (STIKO) had changed the recommendation for individuals $<60$ years of age to receive an mRNA vaccine as boost vaccination to avoid risk of thrombotic complications $(13,16)$. At days $-2 / 0$ before vaccination, days 15-16, 30-37, 53-57 after ChAdOx1 nCoV-19 vaccination, and days 6-11 and 14-19 after heterologous BNT162b2 boost (days 64-65 and 72-73 after ChAdOx1 nCoV-19, respectively), blood was drawn into S-Monovette ${ }^{\circledR}$ Serum Gel (Sarstedt) or S-Monovette ${ }^{\circledR}$ K3 EDTA tubes. Sera from individuals vaccinated twice with BNT162b2 were obtained 13-15 days after the second dose under approval by the ethics committee of Ulm university (31/21); these sera were previously described and re-analyzed for this study(24). Serum Gel collection tubes were centrifuged at 1,500 $\times \mathrm{g}$ at $20^{\circ} \mathrm{C}$ for $15 \mathrm{~min}$, aliquoted stored at $-20^{\circ} \mathrm{C}$ until further use. Peripheral blood mononuclear cells (PBMCs) were obtained from EDTA tubes using density gradient centrifugation by Pancoll human (Pan Biotech, Germany), and erythrocytes removed by ACK lysis buffer (Lonza, Walkersville, MD, U.S.A). Mononuclear cells were counted for viability using a Countess II Automated Cell Counter (Thermo Fisher) with trypan blue stain and were cryopreserved in aliquots of up to $1 \times 10^{7}$ cells in $10 \%$ DMSO in heat-inactivated FCS.

\section{Vaccine reactogenicity}

Solicited adverse reactions (SAR) were self-reported by the participants via questionnaire following prime and boost vaccination. Participants were asked to list symptoms, their duration $(<$ $1 \mathrm{~h}$, few hours, one day or more than one day) and severity (mild (grade 1), moderate (grade 2), severe (grade 3). Grading criteria were adapted from the US Department of Health and Human Services CTCEA (Common Terminology Criteria for Adverse Events, v4.03) (23), with grade 12 being considered for some symptoms, grade 1-3 for most. For calculation of cumulative SAR (cSAR) scores, the grades of all symptoms listed were summed up, with an additional score point added for symptoms experienced for more than one day (0-4).

\section{Determination of antibody titers}

IgG and IgA levels in serum were determined by anti-SARS-CoV-2 assay (Euroimmun), an ELISA which detects antibodies against the SARS-CoV-2 S1 spike domain. The assay was performed according to the manufacturer's instructions. Briefly, serum samples were diluted 10fold in sample buffer and pipetted into rSARS-CoV-2 spike precoated strips of eight single wells 
medRxiv preprint doi: https://doi.org/10.1101/2021.05.30.21257971; this version posted July 15, 2021. The copyright holder for this preprint (which was not certified by peer review) is the author/funder, who has granted medRxiv a license to display the preprint in perpetuity.

All rights reserved. No reuse allowed without permission.

of a 96-well microtiter. After incubation for $60 \mathrm{~min}$ at $37^{\circ} \mathrm{C}$, wells were washed three times, peroxidase-labeled anti-IgG or anti-IgA added and incubated. After $30 \mathrm{~min}$, three additional washing steps were performed before substrate was added and incubated for 15-30 min in the dark. Thereafter, stop solution was added, and optical density (OD) values measured on a POLARstar Omega plate reader (BMG LABTECH, Ortenberg, Germany) at $450 \mathrm{~nm}$ corrected for $620 \mathrm{~nm}$. Finally, OD ratios were calculated based on the sample and calibrator OD values, where a ratio $<0.8$ was considered to be negative and $>1 \cdot 1$ to be positive. To quantify antibody responses, $\operatorname{IgG}$ and $\operatorname{IgM}$ were measured as units per $\mathrm{ml}(\mathrm{U} / \mathrm{ml})$ that correlates with the WHO standard unit for the SARS-CoV-2 binding antibody units per $\mathrm{ml}$ (BAU/ml). To this end, serum was analyzed using the commercial electrochemiluminescence Elecsys Anti-SARS-CoV-2 S immunoassay (Roche, Mannheim, Germany) by a cobas ${ }^{\circledR}$ e 801 immunoassay analyzer according to the manufacturer's instructions (Roche).

\section{Surrogate SARS-CoV-2 neutralization test}

Prevention of SARS-CoV-2 spike RBD interaction with ACE2 by sera was evaluated by SARSCoV-2 Surrogate Virus Neutralization Test Kit (GenScript) according to the manufacturer's instructions. To this end, sera were incubated with a peroxidase-conjugated RBD fragment and the mixture added to a human ACE- 2 coated plate, and unbound RBD washed away. Thereafter, substrate was added and the reaction stopped by stopping reagent. ODs at $450 \mathrm{~nm}$ were measured at a microplate reader. The inhibition score compared to the negative control was calculated as percentages. Scores $<20 \%$ were considered negative and scores $>20 \%$ positive.

\section{Cell culture}

Vero E6 (African green monkey, female, kidney; CRL-1586, ATCC, RRID:CVCL_0574) cells were grown in Dulbecco's modified Eagle's medium (DMEM, Gibco) which was supplemented with $2.5 \%$ heat-inactivated fetal calf serum (FCS), 100 units $/ \mathrm{ml}$ penicillin, $100 \mu \mathrm{g} / \mathrm{ml}$ streptomycin, $2 \mathrm{mM}$ L-glutamine, $1 \mathrm{mM}$ sodium pyruvate, and $1 \mathrm{x}$ non-essential amino acids. HEK293T (human, female, kidney; ACC-635, DSMZ, RRID: CVCL_0063) cells were grown in DMEM with supplementation of $10 \% \mathrm{FCS}, 100$ units $/ \mathrm{ml}$ penicillin, $100 \mu \mathrm{g} / \mathrm{ml}$ streptomycin, 2 $\mathrm{mM}$ L-glutamine. All cells were grown at $37^{\circ} \mathrm{C}$ in a $5 \% \mathrm{CO}_{2}$ humidified incubator.

\section{Preparation of pseudotyped particles}

Expression plasmids for vesicular stomatitis virus (VSV, serotype Indiana) glycoprotein (VSV-G) and SARS-2-S variants B.1.1.7, B.1.351 and B.1.617 (codon-optimized; with a C-terminal truncation of 18 amino acid residues) have been described elsewhere $(24,42)$. Transfection of cells was carried out by Transit LT-1 (Mirus). Rhabdoviral pseudotype particles were prepared as previously described (43). A replication-deficient VSV vector in which the genetic information for VSV-G was replaced by genes encoding two reporter proteins, enhanced green fluorescent protein and firefly luciferase (FLuc), VSV* $* \Delta$ GLFuc (44) (kindly provided by Gert Zimmer, Institute of Virology and Immunology, Mittelhäusern, Switzerland) (Berger Rentsch and Zimmer, 2011) was used for pseudotyping. One day after transfection of HEK293T cells to express the viral glycoprotein, they were inoculated with VSV $* \Delta \mathrm{G}$-FLuc and incubated for $1-2 \mathrm{~h}$ at $37^{\circ} \mathrm{C}$. Then the inoculum was removed, cells were washed with PBS and fresh medium added. After 16-18 h, the supernatant was collected and centrifuged $(2,000 \times \mathrm{g}, 10 \mathrm{~min}$, room temperature $)$ to clear cellular debris. Cell culture medium containing anti-VSV-G antibody (I1-hybridoma cells; ATCC no. 
medRxiv preprint doi: https://doi.org/10.1101/2021.05.30.21257971; this version posted July 15, 2021. The copyright holder for this preprint (which was not certified by peer review) is the author/funder, who has granted medRxiv a license to display the preprint in perpetuity.

All rights reserved. No reuse allowed without permission.

CRL-2700) was then added to block residual VSV-G-containing particles. Samples were then aliquoted and stored at $-80^{\circ} \mathrm{C}$.

\section{Pseudovirus neutralisation assay}

For pseudovirus neutralisation experiments, VeroE6 were seeded in 96-well plates one day prior (6,000 cells/well). Heat-inactivated $\left(56^{\circ} \mathrm{C}, 30 \mathrm{~min}\right)$ sera were serially titrated in PBS, pseudovirus stocks added $(1: 1, \mathrm{v} / \mathrm{v})$ and the mixtures incubated for $30 \mathrm{~min}$ at $37^{\circ} \mathrm{C}$ before being added to cells. After an incubation period of 16-18 h, transduction efficiency was analyzed. For this, the supernatant was removed, and cells were lysed by incubation with Cell Culture Lysis Reagent (Promega) at room temperature. Lysates were then transferred into white 96-well plates and FLuc activity was measured using a commercially available substrate (Luciferase Assay System, Promega) and a plate luminometer (Orion II Microplate Luminometer, Berthold). For analysis of raw values (RLU/s), background signal of an uninfected plate was subtracted and values normalized to pseudovirus treated with PBS only. Results are given as serum dilution resulting in $50 \%$ virus neutralization (NT50) on cells, calculated by nonlinear regression ([Inhibitor] vs. normalized response -- Variable slope) in GraphPad Prism Version 9.1.1.

\section{Determination of $\mathrm{CD4}^{+}$and $\mathrm{CD8}^{+} \mathrm{T}$ SARS-CoV-2 spike -specific cell responses by intracellular cytokine staining (ICS)}

Cryopreserved PBMCs of study participants were thawed and rested overnight at $37^{\circ} \mathrm{C}$ with 1 $\mu \mathrm{l} / \mathrm{ml}$ of DNAse (DNase I recombinant, RNase-free (10,000 U) Roche), in RPMI medium supplemented to contain a final concentration of 10\% FCS (Corning Life Sciences/Media Tech Inc, Manassas, VA), $10 \mathrm{mM}$ HEPES, 1x MEM nonessential amino acids (Corning Life Sciences/Media Tech Inc, Manassas, VA), 1 mM Sodium Pyruvate (Lonza, Walkersville, MD, U.S.A), 1mM Penicillin/Streptomycin (Pan Biotech, Germany) and 1x 2-Mercaptoethanol (GIBCO, Invitrogen, Carlsbad, CA, U.S.A). Stimulation of PBMCs for detection of cytokine production by $\mathrm{T}$ cells was adapted from Kasturi et al., 2020 (45). Briefly, 1x106 PBMCs were cultured in $200 \mu \mathrm{l}$ final volume in $96-$ well $\mathrm{U}$ bottom plate in the presence of anti-CD28 $(1 \mu \mathrm{g} / \mathrm{ml})$ and anti-CD49d $(1 \mu \mathrm{g} / \mathrm{ml})$ [Biolegend] under the following conditions: a) negative control with DMSO, b) SARS-CoV-2 spike peptide pools (1-315 peptides from Wuhan-Hu-1, B.1.1.7 (Alpha), B.1.351 (Beta) and P.1 (Gamma) SARS-CoV-2 spike, JPT Germany) at a final concentration of 2 $\mu \mathrm{g} / \mathrm{ml}, \mathrm{c})$ PMA/Ionomycin, d) CEFX Ultra Super Stim peptide pool (176 peptide epitopes for a broad range of HLA subtypes and different infectious agents, JPT Germany) at a final concentration of $2 \mu \mathrm{g} / \mathrm{ml}$. Cells were cultured for 2 hours before adding Brefeldin A at $10 \mu \mathrm{g} / \mathrm{ml}$ (Sigma-Aldrich, St Louis, MO) for an additional 5 hours. Cells were then washed with PBS, and stained for dead cells (Live/ Dead Fixable; Aqua from Thermo Fisher) in PBS at room temperature for 10 minutes. Without washing, cells were incubated with surface antibody cocktail (prepared in 1:1 of FACS buffer and brilliant staining buffer) for 30 minutes at room temperature with BV510anti-human CD14 (clone M5E2), BV510-anti-human CD19 (clone HIB19), AF700 anti-human CD3 (clone OKT3), BV605 CD4 (clone OKT4), PerCP-Cy5.5 CD8 (clone RPA-T8) from Biolegend. Next, cells were fixed using Cytofix/Cytoperm buffer (BD Biosciences, CA) for 20 minutes at room temperature, and then kept in FACS buffer at $4^{\circ} \mathrm{C}$ overnight. 1x Perm/Wash (BD Biosciences, CA) was used for cells permeabilization for 10 minutes at room temperature and followed by intracellular staining for 30 minutes at room temperature with AF647 anti-human IFN $\gamma$ (clone 4S.B3) and AF488 anti- human IL-2 (clone MQ1-17H12) from Biolegend, and PE/Cy7 anti- human TNFa (clone Mab11) from Thermo Fisher Scientific. Up to 100,000 live 
medRxiv preprint doi: https://doi.org/10.1101/2021.05.30.21257971; this version posted July 15, 2021. The copyright holder for this preprint (which was not certified by peer review) is the author/funder, who has granted medRxiv a license to display the preprint in perpetuity.

All rights reserved. No reuse allowed without permission.

$\mathrm{CD}^{+} \mathrm{T}$ cells were acquired on a LSRFortessa flow cytometer (BD Biosciences), equipped with FACS Diva software. Analysis of the acquired data was performed using FlowJo software (version 10.7.1). The background from each participant was removed by subtracting the $\%$ of spike ${ }^{+}$cells to the $\%$ of $\mathrm{DMSO}^{+}$cells. An arbitrary value below $0.01 \%$ of $\mathrm{CD}^{+} / \mathrm{CD}^{+} \mathrm{T}$ cells was considered negative.

\section{Statistical analysis}

The SARS-CoV-2 convalescent individual was excluded in all statistical analyses. Non-parametric Spearman rank correlation was used to check for possible associations at single blood sample measurements. A paired t-test was used to compare the adverse event scores calculated for each participant after both vaccinations. For this, the individual mean differences were checked for normal distribution by means of QQ-plots and histograms. A comparison of participants receiving heterologous vaccination with controls who received homologous BNT162b2 vaccinations after the last blood sample measurements was done by the Mann-Whitney-U test because of skewed distributions for neutralization scores as well as $\operatorname{IgM/IgG~measurements.~Longitudinal~antibody~}$ measurements were analyzed by means of a mixed linear regression model including a random intercept in order to account for the repeated measures structure of the underlying data. The mixed linear model approach enabled to simultaneously account for possible confounding due to participants' sex and for the presence of missing data (46). Therefore, no formal imputation of missing interim values was required. A two-sided alpha error of 5\% was applied to analyses. Analysis of repetitive measurements of sera provided by a cohort of 26 participants can be considered statistically valid. T cell reactivity before vaccination and 72-73 days after prime (2 weeks after boost) or between variants was compared with Wilcoxon matched-pairs signed rank test. All analyses were done by GraphPad Prism version 9.1.1 for Windows, GraphPad Software, San Diego, California USA, www.graphpad.com, R (version 4.0.1) and SAS (version 9.4). 
medRxiv preprint doi: https://doi.org/10.1101/2021.05.30.21257971; this version posted July 15, 2021. The copyright holder for this preprint

(which was not certified by peer review) is the author/funder, who has granted medRxiv a license to display the preprint in perpetuity.

All rights reserved. No reuse allowed without permission.

\section{References}

1. World Health Organization. 2020. Pneumonia of unknown cause - China.

2. World Health Organization. 2020. Coronavirus disease 2019 (COVID-19) Situation Report - 75.

3. Mathieu E, Ritchie H, Ortiz-Ospina E, Roser M, Hasell J, Appel C, Giattino C. 2021. A global database of COVID-19 vaccinations. medRxiv 2021.03.22.21254100.

4. Barrett JR, Belij-Rammerstorfer S, Dold C, Ewer KJ, Folegatti PM, Gilbride C, Halkerston R, Hill J, Jenkin D, Stockdale L, Verheul MK, Aley PK, Angus B, Bellamy D, Berrie E, Bibi S, Bittaye M, Carroll MW, Cavell B, Clutterbuck EA, Edwards N, Flaxman A, Fuskova M, Gorringe A, Hallis B, Kerridge S, Lawrie AM, Linder A, Liu X, Madhavan M, Makinson R, Mellors J, Minassian A, Moore M, Mujadidi Y, Plested E, Poulton I, Ramasamy MN, Robinson H, Rollier CS, Song R, Snape MD, Tarrant R, Taylor S, Thomas KM, Voysey M, Watson MEE, Wright D, Douglas AD, Green CM, Hill AVS, Lambe T, Gilbert S, Pollard AJ. 2021. Phase 1/2 trial of SARS-CoV-2 vaccine ChAdOx $1 \mathrm{nCoV}-19$ with a booster dose induces multifunctional antibody responses. Nat Med 27.

5. Ewer KJ, Barrett JR, Belij-Rammerstorfer S, Sharpe H, Makinson R, Morter R, Flaxman A, Wright D, Bellamy D, Bittaye M, Dold C, Provine NM, Aboagye J, Fowler J, Silk SE, Alderson J, Aley PK, Angus B, Berrie E, Bibi S, Cicconi P, Clutterbuck EA, Chelysheva I, Folegatti PM, Fuskova M, Green CM, Jenkin D, Kerridge S, Lawrie A, Minassian AM, Moore M, Mujadidi Y, Plested E, Poulton I, Ramasamy MN, Robinson H, Song R, Snape MD, Tarrant R, Voysey M, Watson MEE, Douglas AD, Hill AVS, Gilbert SC, Pollard AJ, Lambe T, Ali A, Allen E, Baker M, Barnes E, Borthwick N, Boyd A, Brown-O'Sullivan C, Burgoyne J, Byard N, Puig IC, Cappuccini F, Cho JS, Cicconi P, Clark E, Crocker WEM, Datoo MS, Davies H, Dunachie SJ, Edwards NJ, Elias SC, Furze J, Gilbride C, Harris SA, Hodgson SHC, Hou MM, Jackson S, Jones K, Kailath R, King L, Larkworthy CW, Li Y, Lias AM, Linder A, Lipworth S, Ramon RL, Madhavan M, Marlow E, Marshall JL, Mentzer AJ, Morrison H, Noé A, Pipini D, Pulido-Gomez D, Lopez FR, Ritchie AJ, Rudiansyah I, Sanders H, Shea A, Silk S, Spencer AJ, Tanner R, Themistocleous Y, Thomas M, Tran N, Truby A, Turner C, Turner N, Ulaszewska M, Worth AT, Kingham-Page L, Alvarez MPP, Anslow R, Bates L, Beadon K, Beckley R, Beveridge A, Bijker EM, Blackwell L, Burbage J, Camara S, Carr M, Colin-Jones R, Cooper R, Cunningham CJ, Demissie T, Maso C Di, Douglas N, Drake-Brockman R, Drury RE, Emary KRW, Felle S, Feng S, Ford KJ, Francis E, Gracie L, Hamlyn J, Hanumunthadu B, Harrison D, Hart TC, Hawkins S, Hill J, Howe E, Howell N, Jones E, Keen J, Kelly S, Kerr D, Khan L, Kinch J, Koleva S, Lees EA, Lelliott A, Liu X, Marinou S, McEwan J, Morey E, Morshead G, Muller J, Munro C, Murphy S, Mweu P, Nuthall E, O’Brien K, O'Connor D, O'Reilly PJ, Oguti B, Osborne P, Owino N, Parker K, Pfafferott K, Provstgaard-Morys S, Ratcliffe H, Rawlinson T, Rhead S, Roberts H, Sanders K, SilvaReyes L, Smith CC, Smith DJ, Szigeti A, Thomas TM, Thompson A, Tonks S, Varughes R, Vichos I, Walker L, White C, White R, Yao XL, Conlon CP, Frater J, Cifuentes L, Baleanu I, Bolam E, Boland E, Brenner T, Damratoski BE, Datta C, Muhanna O El, Fisher R, Galian-Rubio P, Hodges G, Jackson F, Liu S, Loew L, Morgans R, Morris SJ, 
medRxiv preprint doi: https://doi.org/10.1101/2021.05.30.21257971; this version posted July 15, 2021. The copyright holder for this preprint (which was not certified by peer review) is the author/funder, who has granted medRxiv a license to display the preprint in perpetuity. All rights reserved. No reuse allowed without permission.

Olchawski V, Oliveria C, Parracho H, Pabon ER, Tahiri-Alaoui A, Taylor K, Williams P, Zizi D, Arbe-Barnes EH, Baker P, Batten A, Downing C, Drake J, English MR, Henry JA, Iveson P, Killen A, King TB, Larwood JPJ, Mallett G, Mansatta K, Mirtorabi N, PatrickSmith M, Perring J, Radia K, Roche S, Schofield E, Naude R te W, Towner J, Baker N, Bewley KR, Brunt E, Buttigieg KR, Charlton S, Coombes NS, Elmore MJ, Godwin K, Hallis B, Knott D, McInroy L, Shaik I, Thomas K, Tree JA, Blundell CL, Cao M, Kelly D, Skelly DT, Themistocleous A, Dong T, Field S, Hamilton E, Kelly E, Klenerman P, Knight JC, Lie Y, Petropoulos C, Sedik C, Wrin T, Meddaugh G, Peng Y, Screaton G, Stafford E. 2021. T cell and antibody responses induced by a single dose of ChAdOx1 nCoV-19 (AZD1222) vaccine in a phase 1/2 clinical trial. Nat Med 27:270-278.

6. Folegatti PM, Ewer KJ, Aley PK, Angus B, Becker S, Belij-Rammerstorfer S, Bellamy D, Bibi S, Bittaye M, Clutterbuck EA, Dold C, Faust SN, Finn A, Flaxman AL, Hallis B, Heath P, Jenkin D, Lazarus R, Makinson R, Minassian AM, Pollock KM, Ramasamy M, Robinson H, Snape M, Tarrant R, Voysey M, Green C, Douglas AD, Hill AVS, Lambe T, Gilbert SC, Pollard AJ, Aboagye J, Adams K, Ali A, Allen E, Allison JL, Anslow R, Arbe-Barnes EH, Babbage G, Baillie K, Baker M, Baker N, Baker P, Baleanu I, Ballaminut J, Barnes E, Barrett J, Bates L, Batten A, Beadon K, Beckley R, Berrie E, Berry L, Beveridge A, Bewley KR, Bijker EM, Bingham T, Blackwell L, Blundell CL, Bolam E, Boland E, Borthwick N, Bower T, Boyd A, Brenner T, Bright PD, BrownO’Sullivan C, Brunt E, Burbage J, Burge S, Buttigieg KR, Byard N, Cabera Puig I, Calvert A, Camara S, Cao M, Cappuccini F, Carr M, Carroll MW, Carter V, Cathie K, Challis RJ, Charlton S, Chelysheva I, Cho J-S, Cicconi P, Cifuentes L, Clark H, Clark E, Cole T, Colin-Jones R, Conlon CP, Cook A, Coombes NS, Cooper R, Cosgrove CA, Coy K, Crocker WEM, Cunningham CJ, Damratoski BE, Dando L, Datoo MS, Davies H, De Graaf H, Demissie T, Di Maso C, Dietrich I, Dong T, Donnellan FR, Douglas N, Downing C, Drake J, Drake-Brockman R, Drury RE, Dunachie SJ, Edwards NJ, Edwards FDL, Edwards CJ, Elias SC, Elmore MJ, Emary KRW, English MR, Fagerbrink S, Felle S, Feng S, Field S, Fixmer C, Fletcher C, Ford KJ, Fowler J, Fox P, Francis E, Frater J, Furze J, Fuskova M, Galiza E, Gbesemete D, Gilbride C, Godwin K, Gorini G, Goulston L, Grabau C, Gracie L, Gray Z, Guthrie LB, Hackett M, Halwe S, Hamilton E, Hamlyn J, Hanumunthadu B, Harding I, Harris SA, Harris A, Harrison D, Harrison C, Hart TC, Haskell L, Hawkins S, Head I, Henry JA, Hill J, Hodgson SHC, Hou MM, Howe E, Howell N, Hutlin C, Ikram S, Isitt C, Iveson P, Jackson S, Jackson F, James SW, Jenkins M, Jones E, Jones K, Jones CE, Jones B, Kailath R, Karampatsas K, Keen J, Kelly S, Kelly D, Kerr D, Kerridge S, Khan L, Khan U, Killen A, Kinch J, King TB, King L, King J, Kingham-Page L, Klenerman P, Knapper F, Knight JC, Knott D, Koleva S, Kupke A, Larkworthy CW, Larwood JPJ, Laskey A, Lawrie AM, Lee A, Ngan Lee KY, Lees EA, Legge H, Lelliott A, Lemm N-M, Lias AM, Linder A, Lipworth S, Liu X, Liu S, Lopez Ramon R, Lwin M, Mabesa F, Madhavan M, Mallett G, Mansatta K, Marcal I, Marinou S, Marlow E, Marshall JL, Martin J, McEwan J, McInroy L, Meddaugh G, Mentzer AJ, Mirtorabi N, Moore M, Moran E, Morey E, Morgan V, Morris SJ, Morrison H, Morshead G, Morter R, Mujadidi YF, Muller J, Munera-Huertas T, Munro C, Munro A, Murphy S, Munster VJ, Mweu P, Noé A, Nugent FL, Nuthall E, O’Brien K, O’Connor D, Oguti B, Oliver JL, Oliveira C, O'Reilly PJ, Osborn M, Osborne P, Owen C, Owens D, Owino N, Pacurar M, Parker K, Parracho H, Patrick-Smith M, Payne V, Pearce J, Peng Y, Peralta Alvarez MP, Perring J, Pfafferott K, Pipini D, Plested E, Pluess-Hall H, Pollock K, 
medRxiv preprint doi: https://doi.org/10.1101/2021.05.30.21257971; this version posted July 15, 2021. The copyright holder for this preprint (which was not certified by peer review) is the author/funder, who has granted medRxiv a license to display the preprint in perpetuity. All rights reserved. No reuse allowed without permission.

Poulton I, Presland L, Provstgaard-Morys S, Pulido D, Radia K, Ramos Lopez F, Rand J, Ratcliffe H, Rawlinson T, Rhead S, Riddell A, Ritchie AJ, Roberts H, Robson J, Roche S, Rohde C, Rollier CS, Romani R, Rudiansyah I, Saich S, Sajjad S, Salvador S, Sanchez Riera L, Sanders H, Sanders K, Sapaun S, Sayce C, Schofield E, Screaton G, Selby B, Semple C, Sharpe HR, Shaik I, Shea A, Shelton H, Silk S, Silva-Reyes L, Skelly DT, Smee H, Smith CC, Smith DJ, Song R, Spencer AJ, Stafford E, Steele A, Stefanova E, Stockdale L, Szigeti A, Tahiri-Alaoui A, Tait M, Talbot H, Tanner R, Taylor IJ, Taylor V, Te Water Naude R, Thakur N, Themistocleous Y, Themistocleous A, Thomas M, Thomas TM, Thompson A, Thomson-Hill S, Tomlins J, Tonks S, Towner J, Tran N, Tree JA, Truby A, Turkentine K, Turner C, Turner N, Turner S, Tuthill T, Ulaszewska M, Varughese R, Van Doremalen N, Veighey K, Verheul MK, Vichos I, Vitale E, Walker L, Watson MEE, Welham B, Wheat J, White C, White R, Worth AT, Wright D, Wright S, Yao XL, Yau Y. 2020. Safety and immunogenicity of the ChAdOx1 nCoV-19 vaccine against SARS-CoV-2: a preliminary report of a phase 1/2, single-blind, randomised controlled trial. Lancet 396:467-478.

7. Sahin U, Muik A, Vogler I, Derhovanessian E, Kranz LM, Vormehr M, Quandt J, Bidmon N, Ulges A, Baum A, Pascal K, Maurus D, Brachtendorf S, Lörks V, Sikorski J, Koch P, Hilker R, Becker D, Eller AK, Grützner J, Tonigold M, Boesler C, Rosenbaum C, Heesen L, Kühnle MC, Poran A, Dong JZ, Luxemburger U, Kemmer-Brück A, Langer D, Bexon M, Bolte S, Palanche T, Schultz A, Baumann S, Mahiny AJ, Boros G, Reinholz J, Szabó GT, Karikó K, Shi PY, Fontes-Garfias C, Perez JL, Cutler M, Cooper D, Kyratsous CA, Dormitzer PR, Jansen KU, Türeci Ö. 2020. BNT162b2 induces SARS-CoV-2-neutralising antibodies and $\mathrm{T}$ cells in humans. medRxiv.

8. Ramasamy MN, Minassian AM, Ewer KJ, Flaxman AL, Folegatti PM, Owens DR, Voysey M, Aley PK, Angus B, Babbage G, Belij-Rammerstorfer S, Berry L, Bibi S, Bittaye M, Cathie K, Chappell H, Charlton S, Cicconi P, Clutterbuck EA, Colin-Jones R, Dold C, Emary KRW, Fedosyuk S, Fuskova M, Gbesemete D, Green C, Hallis B, Hou MM, Jenkin D, Joe CCD, Kelly EJ, Kerridge S, Lawrie AM, Lelliott A, Lwin MN, Makinson R, Marchevsky NG, Mujadidi Y, Munro APS, Pacurar M, Plested E, Rand J, Rawlinson T, Rhead S, Robinson H, Ritchie AJ, Ross-Russell AL, Saich S, Singh N, Smith CC, Snape MD, Song R, Tarrant R, Themistocleous Y, Thomas KM, Villafana TL, Warren SC, Watson MEE, Douglas AD, Hill AVS, Lambe T, Gilbert SC, Faust SN, Pollard AJ, Aboagye J, Adams K, Ali A, Allen ER, Allen L, Allison JL, Andritsou F, Anslow R, Arbe-Barnes EH, Baker M, Baker N, Baker P, Baleanu I, Barker D, Barnes E, Barrett JR, Barrett K, Bates L, Batten A, Beadon K, Beckley R, Bellamy D, Berg A, Bermejo L, Berrie E, Beveridge A, Bewley K, Bijker EM, Birch G, Blackwell L, Bletchly H, Blundell CL, Blundell SR, Bolam E, Boland E, Bormans D, Borthwick N, Boukas K, Bower T, Bowring F, Boyd A, Brenner T, Brown P, Brown-O'Sullivan C, Bruce S, Brunt E, Burbage J, Burgoyne J, Buttigieg KR, Byard N, Cabera Puig I, Camara S, Cao M, Cappuccini F, Carr M, Carroll MW, Cashen P, Cavey A, Chadwick J, Challis R, Chapman D, Charles D, Chelysheva I, Cho J-S, Cifuentes L, Clark E, Collins S, Conlon CP, Coombes NS, Cooper R, Cooper C, Crocker WEM, Crosbie S, Cullen D, Cunningham C, Cuthbertson F, Datoo BE, Dando L, Datoo MS, Datta C, Davies H, Davies S, Davis EJ, Davis J, Dearlove D, Demissie T, Di Marco S, Di Maso C, DiTirro D, Docksey C, Dong T, Donnellan FR, Douglas N, Downing C, Drake J, Drake-Brockman R, Drury RE, Dunachie SJ, Edwards CJ, Edwards NJ, El Muhanna O, Elias SC, Elliott RS, Elmore MJ, 
medRxiv preprint doi: https://doi.org/10.1101/2021.05.30.21257971; this version posted July 15, 2021. The copyright holder for this preprint (which was not certified by peer review) is the author/funder, who has granted medRxiv a license to display the preprint in perpetuity. All rights reserved. No reuse allowed without permission.

English MR, Felle S, Feng S, Ferreira Da Silva C, Field S, Fisher R, Fixmer C, Ford KJ, Fowler J, Francis E, Frater J, Furze J, Galian-Rubio P, Galloway C, Garlant H, Gavrila M, Gibbons F, Gibbons K, Gilbride C, Gill H, Godwin K, Gordon-Quayle K, Gorini G, Goulston L, Grabau C, Gracie L, Graham N, Greenwood N, Griffiths O, Gupta G, Hamilton E, Hanumunthadu B, Harris SA, Harris T, Harrison D, Hart TC, Hartnell B, Haskell L, Hawkins S, Henry JA, Hermosin Herrera M, Hill D, Hill J, Hodges G, Hodgson SHC, Horton KL, Howe E, Howell N, Howes J, Huang B, Humphreys J, Humphries HE, Iveson P, Jackson F, Jackson S, Jauregui S, Jeffers H, Jones B, Jones CE, Jones E, Jones K, Joshi A, Kailath R, Keen J, Kelly DM, Kelly S, Kelly D, Kerr D, Khan L, Khozoee B, Killen A, Kinch J, King LDW, King TB, Kingham L, Klenerman P, Knight JC, Knott D, Koleva S, Lang G, Larkworthy CW, Larwood JPJ, Law R, Lee A, Lee KYN, Lees EA, Leung S, Li Y, Lias AM, Linder A, Lipworth S, Liu S, Liu X, Lloyd S, Loew L, Lopez Ramon R, Madhavan M, Mainwaring DO, Mallett G, Mansatta K, Marinou S, Marius P, Marlow E, Marriott P, Marshall JL, Martin J, Masters S, McEwan J, McGlashan JL, McInroy L, McRobert N, Megson C, Mentzer AJ, Mirtorabi N, Mitton C, Moore M, Moran M, Morey E, Morgans R, Morris SJ, Morrison HM, Morshead G, Morter R, Moya NA, Mukhopadhyay E, Muller J, Munro C, Murphy S, Mweu P, Noé A, Nugent FL, O'Brien K, O'Connor D, Oguti B, Olchawski V, Oliveira C, O'Reilly PJ, Osborne P, Owen L, Owino N, Papageorgiou P, Parracho H, Parsons K, Patel B, Patrick-Smith M, Peng Y, Penn EJ, Peralta-Alvarez MP, Perring J, Petropoulos C, Phillips DJ, Pipini D, Pollard S, Poulton I, Pratt D, Presland L, Proud PC, Provstgaard-Morys S, Pueschel S, Pulido D, Rabara R, Radia K, Rajapaska D, Ramos Lopez F, Ratcliffe H, Rayhan S, Rees B, Reyes Pabon E, Roberts H, Robertson I, Roche S, Rollier CS, Romani R, Rose Z, Rudiansyah I, Sabheha S, Salvador S, Sanders H, Sanders K, Satti I, Sayce C, Schmid AB, Schofield E, Screaton G, Sedik C, Seddiqi S, Segireddy RR, Selby B, Shaik I, Sharpe HR, Shaw R, Shea A, Silk S, Silva-Reyes L, Skelly DT, Smith DJ, Smith DC, Smith N, Spencer AJ, Spoors L, Stafford E, Stamford I, Stockdale L, Stockley D, Stockwell L V., Stokes M, Strickland LH, Stuart A, Sulaiman S, Summerton E, Swash Z, Szigeti A, Tahiri-Alaoui A, Tanner R, Taylor I, Taylor K, Taylor U, te Water Naude R, Themistocleous A, Thomas M, Thomas TM, Thompson A, Thompson K, Thornton-Jones V, Tinh L, Tomic A, Tonks S, Towner J, Tran N, Tree JA, Truby A, Turner C, Turner R, Ulaszewska M, Varughese R, Verbart D, Verheul MK, Vichos I, Walker L, Wand ME, Watkins B, Welch J, West AJ, White C, White R, Williams P, Woodyer M, Worth AT, Wright D, Wrin T, Yao XL, Zbarcea D-A, Zizi D. 2020. Safety and immunogenicity of ChAdOx $1 \mathrm{nCoV}-19$ vaccine administered in a prime-boost regimen in young and old adults (COV002): a single-blind, randomised, controlled, phase 2/3 trial. Lancet 396:1979-1993.

9. Voysey M, Clemens SAC, Madhi SA, Weckx LY, Folegatti PM, Aley PK, Angus B, Baillie VL, Barnabas SL, Bhorat QE, Bibi S, Briner C, Cicconi P, Collins AM, ColinJones R, Cutland CL, Darton TC, Dheda K, Duncan CJA, Emary KRW, Ewer KJ, Fairlie L, Faust SN, Feng S, Ferreira DM, Finn A, Goodman AL, Green CM, Green CA, Heath PT, Hill C, Hill H, Hirsch I, Hodgson SHC, Izu A, Jackson S, Jenkin D, Joe CCD, Kerridge S, Koen A, Kwatra G, Lazarus R, Lawrie AM, Lelliott A, Libri V, Lillie PJ, Mallory R, Mendes AVA, Milan EP, Minassian AM, McGregor A, Morrison H, Mujadidi YF, Nana A, O'Reilly PJ, Padayachee SD, Pittella A, Plested E, Pollock KM, Ramasamy MN, Rhead S, Schwarzbold A V., Singh N, Smith A, Song R, Snape MD, Sprinz E, 
medRxiv preprint doi: https://doi.org/10.1101/2021.05.30.21257971; this version posted July 15, 2021. The copyright holder for this preprint

(which was not certified by peer review) is the author/funder, who has granted medRxiv a license to display the preprint in perpetuity.

All rights reserved. No reuse allowed without permission.

Sutherland RK, Tarrant R, Thomson EC, Török ME, Toshner M, Turner DPJ, Vekemans J, Villafana TL, Watson MEE, Williams CJ, Douglas AD, Hill AVS, Lambe T, Gilbert SC, Pollard AJ, Aban M, Abayomi F, Abeyskera K, Aboagye J, Adam M, Adams K, Adamson J, Adelaja YA, Adewetan G, Adlou S, Ahmed K, Akhalwaya Y, Akhalwaya S, Alcock A, Ali A, Allen ER, Allen L, Almeida TCDSC, Alves MPS, Amorim F, Andritsou F, Anslow R, Appleby M, Arbe-Barnes EH, Ariaans MP, Arns B, Arruda L, Azi P, Azi L, Babbage G, Bailey C, Baker KF, Baker M, Baker N, Baker P, Baldwin L, Baleanu I, Bandeira D, Bara A, Barbosa MAS, Barker D, Barlow GD, Barnes E, Barr AS, Barrett JR, Barrett J, Bates L, Batten A, Beadon K, Beales E, Beckley R, Belij-Rammerstorfer S, Bell J, Bellamy D, Bellei N, Belton S, Berg A, Bermejo L, Berrie E, Berry L, Berzenyi D, Beveridge A, Bewley KR, Bexhell H, Bhikha S, Bhorat AE, Bhorat ZE, Bijker E, Birch G, Birch S, Bird A, Bird O, Bisnauthsing K, Bittaye M, Blackstone K, Blackwell L, Bletchly H, Blundell CL, Blundell SR, Bodalia P, Boettger BC, Bolam E, Boland E, Bormans D, Borthwick N, Bowring F, Boyd A, Bradley P, Brenner T, Brown P, Brown C, Brown-O’Sullivan C, Bruce S, Brunt E, Buchan R, Budd W, Bulbulia YA, Bull M, Burbage J, Burhan H, Burn A, Buttigieg KR, Byard N, Cabera Puig I, Calderon G, Calvert A, Camara S, Cao M, Cappuccini F, Cardoso JR, Carr M, Carroll MW, Carson-Stevens A, Carvalho Y de M, Carvalho JAM, Casey HR, Cashen P, Castro T, Castro LC, Cathie K, Cavey A, Cerbino-Neto J, Chadwick J, Chapman D, Charlton S, Chelysheva I, Chester O, Chita S, Cho JS, Cifuentes L, Clark E, Clark M, Clarke A, Clutterbuck EA, Collins SLK, Conlon CP, Connarty S, Coombes N, Cooper C, Cooper R, Cornelissen L, Corrah T, Cosgrove C, Cox T, Crocker WEM, Crosbie S, Cullen L, Cullen D, Cunha DRMF, Cunningham C, Cuthbertson FC, Da Guarda SNF, da Silva LP, Damratoski BE, Danos Z, Dantas MTDC, Darroch P, Datoo MS, Datta C, Davids M, Davies SL, Davies H, Davis E, Davis J, Davis J, De Nobrega MMD, De Oliveira Kalid LM, Dearlove D, Demissie T, Desai A, Di Marco S, Di Maso C, Dinelli MIS, Dinesh T, Docksey C, Dold C, Dong T, Donnellan FR, Dos Santos T, dos Santos TG, Dos Santos EP, Douglas N, Downing C, Drake J, Drake-Brockman R, Driver K, Drury R, Dunachie SJ, Durham BS, Dutra L, Easom NJW, van Eck S, Edwards M, Edwards NJ, El Muhanna OM, Elias SC, Elmore M, English M, Esmail A, Essack YM, Farmer E, Farooq M, Farrar M, Farrugia L, Faulkner B, Fedosyuk S, Felle S, Ferreira Da Silva C, Field S, Fisher R, Flaxman A, Fletcher J, Fofie H, Fok H, Ford KJ, Fowler J, Fraiman PHA, Francis E, Franco MM, Frater J, Freire MSM, Fry SH, Fudge S, Furze J, Fuskova M, Galian-Rubio P, Galiza E, Garlant H, Gavrila M, Geddes A, Gibbons KA, Gilbride C, Gill H, Glynn S, Godwin K, Gokani K, Goldoni UC, Goncalves M, Gonzalez IGS, Goodwin J, Goondiwala A, Gordon-Quayle K, Gorini G, Grab J, Gracie L, Greenland M, Greenwood N, Greffrath J, Groenewald MM, Grossi L, Gupta G, Hackett M, Hallis B, Hamaluba M, Hamilton E, Hamlyn J, Hammersley D, Hanrath AT, Hanumunthadu B, Harris SA, Harris C, Harris T, Harrison TD, Harrison D, Hart TC, Hartnell B, Hassan S, Haughney J, Hawkins S, Hay J, Head I, Henry J, Hermosin Herrera M, Hettle DB, Hill J, Hodges G, Horne E, Hou MM, Houlihan C, Howe E, Howell N, Humphreys J, Humphries HE, Hurley K, Huson C, Hyder-Wright A, Hyams C, Ikram S, Ishwarbhai A, Ivan M, Iveson P, Iyer V, Jackson F, De Jager J, Jaumdally S, Jeffers H, Jesudason N, Jones B, Jones K, Jones E, Jones C, Jorge MR, Jose A, Joshi A, Júnior EAMS, Kadziola J, Kailath R, Kana F, Karampatsas K, Kasanyinga M, Keen J, Kelly EJ, Kelly DM, Kelly D, Kelly S, Kerr D, Kfouri R de Á, Khan L, Khozoee B, Kidd S, Killen A, Kinch J, Kinch P, King LDW, King TB, Kingham L, Klenerman P, 
medRxiv preprint doi: https://doi.org/10.1101/2021.05.30.21257971; this version posted July 15, 2021. The copyright holder for this preprint

(which was not certified by peer review) is the author/funder, who has granted medRxiv a license to display the preprint in perpetuity.

All rights reserved. No reuse allowed without permission.

Knapper F, Knight JC, Knott D, Koleva S, Lang M, Lang G, Larkworthy CW, Larwood JPJ, Law R, Lazarus EM, Leach A, Lees EA, Lemm NM, Lessa A, Leung S, Li Y, Lias AM, Liatsikos K, Linder A, Lipworth S, Liu S, Liu X, Lloyd A, Lloyd S, Loew L, Lopez Ramon R, Lora L, Lowthorpe V, Luz K, MacDonald JC, MacGregor G, Madhavan M, Mainwaring DO, Makambwa E, Makinson R, Malahleha M, Malamatsho R, Mallett G, Mansatta K, Maoko T, Mapetla K, Marchevsky NG, Marinou S, Marlow E, Marques GN, Marriott P, Marshall RP, Marshall JL, Martins FJ, Masenya M, Masilela M, Masters SK, Mathew M, Matlebjane H, Matshidiso K, Mazur O, Mazzella A, McCaughan H, McEwan J, McGlashan J, McInroy L, McIntyre Z, McLenaghan D, McRobert N, McSwiggan S, Megson C, Mehdipour S, Meijs W, Mendonça RNÁ, Mentzer AJ, Mirtorabi N, Mitton C, Mnyakeni S, Moghaddas F, Molapo K, Moloi M, Moore M, Moraes-Pinto MI, Moran M, Morey E, Morgans R, Morris S, Morris S, Morris HC, Morselli F, Morshead G, Morter R, Mottal L, Moultrie A, Moya N, Mpelembue M, Msomi S, Mugodi Y, Mukhopadhyay E, Muller J, Munro A, Munro C, Murphy S, Mweu P, Myasaki CH, Naik G, Naker K, Nastouli E, Nazir A, Ndlovu B, Neffa F, Njenga C, Noal H, Noé A, Novaes G, Nugent FL, Nunes G, O’Brien K, O’Connor D, Odam M, Oelofse S, Oguti B, Olchawski V, Oldfield NJ, Oliveira MG, Oliveira C, Oosthuizen A, O'Reilly P, Osborne P, Owen DRJ, Owen L, Owens D, Owino N, Pacurar M, Paiva BVB, Palhares EMF, Palmer S, Parkinson S, Parracho HMRT, Parsons K, Patel D, Patel B, Patel F, Patel K, Patrick-Smith M, Payne RO, Peng Y, Penn EJ, Pennington A, Peralta Alvarez MP, Perring J, Perry N, Perumal R, Petkar S, Philip T, Phillips DJ, Phillips J, Phohu MK, Pickup L, Pieterse S, Piper J, Pipini D, Plank M, Du Plessis J, Pollard S, Pooley J, Pooran A, Poulton I, Powers C, Presa FB, Price DA, Price V, Primeira M, Proud PC, Provstgaard-Morys S, Pueschel S, Pulido D, Quaid S, Rabara R, Radford A, Radia K, Rajapaska D, Rajeswaran T, Ramos ASF, Ramos Lopez F, Rampling T, Rand J, Ratcliffe H, Rawlinson T, Rea D, Rees B, Reiné J, Resuello-Dauti M, Reyes Pabon E, Ribiero CM, Ricamara M, Richter A, Ritchie N, Ritchie AJ, Robbins AJ, Roberts H, Robinson RE, Robinson H, Rocchetti TT, Rocha BP, Roche S, Rollier C, Rose L, Ross Russell AL, Rossouw L, Royal S, Rudiansyah I, Ruiz S, Saich S, Sala C, Sale J, Salman AM, Salvador N, Salvador S, Sampaio M, Samson AD, Sanchez-Gonzalez A, Sanders H, Sanders K, Santos E, Santos Guerra MFS, Satti I, Saunders JE, Saunders C, Sayed A, Schim van der Loeff I, Schmid AB, Schofield E, Screaton G, Seddiqi S, Segireddy RR, Senger R, Serrano S, Shah R, Shaik I, Sharpe HE, Sharrocks K, Shaw R, Shea A, Shepherd A, Shepherd JG, Shiham F, Sidhom E, Silk SE, da Silva Moraes AC, Silva-Junior G, Silva-Reyes L, Silveira AD, Silveira MBV, Sinha J, Skelly DT, Smith DC, Smith N, Smith HE, Smith DJ, Smith CC, Soares A, Soares T, Solórzano C, Sorio GL, Sorley K, Sosa-Rodriguez T, Souza CMCDL, Souza BSDF, Souza AR, Spencer AJ, Spina F, Spoors L, Stafford L, Stamford I, Starinskij I, Stein R, Steven J, Stockdale L, Stockwell L V., Strickland LH, Stuart AC, Sturdy A, Sutton N, Szigeti A, Tahiri-Alaoui A, Tanner R, Taoushanis C, Tarr AW, Taylor K, Taylor U, Taylor IJ, Taylor J, te Water Naude R, Themistocleous Y, Themistocleous A, Thomas M, Thomas K, Thomas TM, Thombrayil A, Thompson F, Thompson A, Thompson K, Thompson A, Thomson J, Thornton-Jones V, Tighe PJ, Tinoco LA, Tiongson G, Tladinyane B, Tomasicchio M, Tomic A, Tonks S, Towner J, Tran N, Tree J, Trillana G, Trinham C, Trivett R, Truby A, Tsheko BL, Turabi A, Turner R, Turner C, Ulaszewska M, Underwood BR, Varughese R, Verbart D, Verheul M, Vichos I, Vieira T, Waddington CS, Walker L, Wallis E, Wand M, Warbick D, Wardell T, Warimwe G, Warren SC, 
medRxiv preprint doi: https://doi.org/10.1101/2021.05.30.21257971; this version posted July 15, 2021. The copyright holder for this preprint

Watkins B, Watson E, Webb S, Webb-Bridges A, Webster A, Welch J, Wells J, West A, White C, White R, Williams P, Williams RL, Winslow R, Woodyer M, Worth AT, Wright D, Wroblewska M, Yao A, Zimmer R, Zizi D, Zuidewind P. 2021. Safety and efficacy of the ChAdOx1 nCoV-19 vaccine (AZD1222) against SARS-CoV-2: an interim analysis of four randomised controlled trials in Brazil, South Africa, and the UK. Lancet 397:99-111.

10. Polack FP, Thomas SJ, Kitchin N, Absalon J, Gurtman A, Lockhart S, Perez JL, Pérez Marc G, Moreira ED, Zerbini C, Bailey R, Swanson KA, Roychoudhury S, Koury K, Li P, Kalina W V., Cooper D, Frenck RW, Hammitt LL, Türeci Ö, Nell H, Schaefer A, Ünal S, Tresnan DB, Mather S, Dormitzer PR, Şahin U, Jansen KU, Gruber WC. 2020. Safety and Efficacy of the BNT162b2 mRNA Covid-19 Vaccine. N Engl J Med 383:2603-2615.

11. Haas EJ, Angulo FJ, McLaughlin JM, Anis E, Singer SR, Khan F, Brooks N, Smaja M, Mircus G, Pan K, Southern J, Swerdlow DL, Jodar L, Levy Y, Alroy-Preis S. 2021. Impact and effectiveness of mRNA BNT162b2 vaccine against SARS-CoV-2 infections and COVID-19 cases, hospitalisations, and deaths following a nationwide vaccination campaign in Israel: an observational study using national surveillance data. Lancet 397:1819-1829.

12. Vasileiou E, Simpson CR, Shi T, Kerr S, Agrawal U, Akbari A, Bedston S, Beggs J, Bradley D, Chuter A, de Lusignan S, Docherty AB, Ford D, Hobbs FR, Joy M, Katikireddi SV, Marple J, McCowan C, McGagh D, McMenamin J, Moore E, Murray JL, Pan J, Ritchie L, Shah SA, Stock S, Torabi F, Tsang RS, Wood R, Woolhouse M, Robertson C, Sheikh A. 2021. Interim findings from first-dose mass COVID-19 vaccination roll-out and COVID-19 hospital admissions in Scotland: a national prospective cohort study. Lancet 397:1646-1657.

13. European Medicines Agency. 2021. AstraZeneca's COVID-19 vaccine: EMA finds possible link to very rare cases of unusual blood clots with low blood platelets.

14. Greinacher A, Thiele T, Warkentin TE, Weisser K, Kyrle PA, Eichinger S. 2021. Thrombotic Thrombocytopenia after ChAdOx1 nCov-19 Vaccination. N Engl J Med 110 .

15. Pottegård A, Lund LC, Karlstad Ø, Dahl J, Andersen M, Hallas J, Lidegaard Ø, Tapia G, Gulseth HL, Ruiz PLD, Watle SV, Mikkelsen AP, Pedersen L, Sørensen HT, Thomsen RW, Hviid A. 2021. Arterial events, venous thromboembolism, thrombocytopenia, and bleeding after vaccination with Oxford-AstraZeneca ChAdOx1-S in Denmark and Norway: Population based cohort study. BMJ 373.

16. Robert Koch Institut. 2021. Epidemiologisches Bulletin.

17. Shaw RH, Stuart A, Greenland M, Liu X, Van-Tam JSN, Snape MD. 2021. Heterologous prime-boost COVID-19 vaccination: initial reactogenicity data. Lancet 397:2043-2046.

18. Hillus D, Tober-Lau P, Hastor H, Helbig ET, Lippert LJ, Thibeault C, Solarek A, von Kalle C, Corman VM, Kopankiewicz P, Suttorp N, Bias H, Seybold J, Kurth F, Sander LE. 2021. Reactogenicity of homologous and heterologous prime-boost immunisation with BNT162b2 and ChAdOx1-nCoV19: a prospective cohort study. medRxiv 2021.05.19.21257334.

19. Borobia AM, Carcas AJ, Pérez-Olmeda M, Castaño L, Bertran MJ, García-Pérez J, 
medRxiv preprint doi: https://doi.org/10.1101/2021.05.30.21257971; this version posted July 15, 2021. The copyright holder for this preprint (which was not certified by peer review) is the author/funder, who has granted medRxiv a license to display the preprint in perpetuity.

All rights reserved. No reuse allowed without permission.

Campins M, Portolés A, González-Pérez M, García Morales MT, Arana-Arri E, Aldea M, Díez-Fuertes F, Fuentes I, Ascaso A, Lora D, Imaz-Ayo N, Barón-Mira LE, Agustí A, Pérez-Ingidua C, Gómez de la Cámara A, Arribas JR, Ochando J, Alcamí J, Belda-Iniesta C, Frías J, Martínez de Soto L, Rodríguez Mariblanca A, Díaz García L, Ramírez García E, Seco Meseguer E, Stewart Balbás SM, Marín Candón A, García García I, Urroz Elizalde M, Monserrat Villatoro J, de la Rosa P, Sanz García M, López Crespo C, Mauleón Martínez V, de Madariaga Castell R, Vitón Vara L, García Rodríguez J, Buño A, López Granados E, Cámara C, Rey Cuevas E, Ayllon García P, Jiménez González M, Hernández Rubio V, Moraga Alapont P, Sánchez A, Prieto R, Llorente Gómez S, Miragall Roig C, Aparicio Marlasca M, de la Calle F, Arsuaga M, Duque B, Meijide S, García de Vicuña A, Santorcuato A, Expósito I, de Benito S, Andia J, Castillo C, Irurzun E, Camino J, Temprano M, Goikoetxea J, Bustinza A, Larrea M, Gallego M, García-Vázquez D, de la Hoz AB, Pérez-Nanclares G, Pérez-Guzmán E, Idoyaga E, Lamela A, Oteo J, Castillo de la Osa M, Hernández Gutiérrez L, Andrés Galván ME, Calonge E, Andrés Galván ME, Bermejo M, de la Torre-Tarazona EH, Cascajero A, Fedele G, Perea C, Cervera I, Bodega-Mayor I, Montes-Casado M, Portolés P, Baranda J, Granés L, Lazaar S, Herranz S, Mellado ME, Tortajada M, Malet M, Quesada S, Vilella A, Llupià A, Olivé V, Trilla A, Gómez B, González E, Romero S, Gámez FJ, Casals C, Burunat L, Castelló JJ, Fernández P, Bedini JL, Vila J, Aguilar C, Altadill C, Armadans L, Borras-Bermejo B, Calonge J, Camacho L, Feliu A, Gili G, Llorente C, Martínez-Gómez X, Otero-Romero S, Palacio E, Parés O, Pinós L, Plaza A, Riera J, Rodrigo-Pendás JA, Sans C, Santos J, Torres G, Torrens M, Uriona S, Ballarin Alins E, Pérez Esquirol E, Vendrell Bosch L, Laredo Velasco L, Uribe López D, González Rojano E, Sánchez-Craviotto M, Rivas Paterna AB, Hernán-Gómez TI, Rodríguez Galán N, Gil Marín JA, Álvarez-Morales V, Navalpotro AB, Jiménez-Santamaría MD, Cardós MC, Hermoso E, García-Arenillas M, Pérez Macías N, Domingo Fernández A, López Picado A, Quiñones JM, Deidda N, García-Franco A, Torvisco JM. 2021. Immunogenicity and reactogenicity of BNT162b2 booster in ChAdOx1-S-primed participants (CombiVacS): a multicentre, open-label, randomised, controlled, phase 2 trial. Lancet 6736:1-10.

20. Schmidt T, Klemis V, Schub D, Mihm J, Hielscher F, Marx S, Abu-Omar A, Schneitler S, Becker SL, Gärtner BC, Sester U, Sester M. 2021. Immunogenicity and reactogenicity of a heterologous COVID-19 prime-boost vaccination compared with homologous vaccine regimens. medRxiv 2021.06.13.21258859.

21. Liu X, Shaw RH, Stuart AS, Greenland M, Dinesh T, Provstgaard-Morys S, Clutterbuck E, Ramasamy MN, Aley PK, Farooq Mujadidi Y, Long F, Plested E, Robinson H, Singh N, Walker LL, White R, Andrews N, Cameron JC, Collins AM, Ferreira DM, Hill HC, Green CA, Hallis B, Heath PT, Faust SN, Finn A, Lambe T, Lazarus R, Libri V, Ramsay ME, Read RC, Turner DPJ, Turner PJ, Nguyen-Van-Tam JS, Snape MD, Group C-CS. Safety and Immunogenicity Report from the Com-COV Study - a Single-Blind Randomised Non-Inferiority Trial Comparing Heterologous And Homologous PrimeBoost Schedules with An Adenoviral Vectored and mRNA COVID-19 Vaccine. Prepr with LANCET.

22. Barros-Martins J, Hammerschmidt S, Cossmann A, Odak I, Stankov M V, Morillas Ramos G, Jablonka A, Heidemann A, Ritter C, Friedrichsen M, Schultze-Florey CR, Ravens I, Stefanie W, Bubke A, Ristenpart J, Janssen A, Ssebyatika G, Bernhardt G, 
medRxiv preprint doi: https://doi.org/10.1101/2021.05.30.21257971; this version posted July 15, 2021. The copyright holder for this preprint (which was not certified by peer review) is the author/funder, who has granted medRxiv a license to display the preprint in perpetuity. All rights reserved. No reuse allowed without permission.

Muench JR, Hoffmann M, Poehlmann S, Krey T, Bosnjak B, Foerster R, Behrens GMN. 2021. Humoral and cellular immune response against SARS-CoV-2 variants following heterologous and homologous ChAdOx1 nCoV-19/BNT162b2 vaccination. medRxiv 2021.06.01.21258172.

23. National Cancer Institute (U.S.). 2010. Common terminology criteria for adverse events : (CTCAE).

24. Hoffmann M, Arora P, Groß R, Seidel A, Hörnich BF, Hahn AS, Krüger N, Graichen L, Hofmann-Winkler H, Kempf A, Winkler MS, Schulz S, Jäck H-M, Jahrsdörfer B, Schrezenmeier H, Müller M, Kleger A, Münch J, Pöhlmann S. 2021. SARS-CoV-2 variants B.1.351 and P.1 escape from neutralizing antibodies. Cell 184:2384-2393.e12.

25. Jahrsdörfer B, Groß R, Seidel A, Wettstein L, Ludwig C, Schwarz T, Körper S, Rojewski M, Lotfi R, Weinstock C, Seifried E, Corman VM, Drosten C, Münch J, Schrezenmeier H. 2021. Characterization of the SARS-CoV-2 Neutralization Potential of COVID-19Convalescent Donors. J Immunol 206:2614-2622.

26. Hoffmann M, Kleine-Weber H, Schroeder S, Krüger N, Herrler T, Erichsen S, Schiergens TS, Herrler G, Wu NH, Nitsche A, Müller MA, Drosten C, Pöhlmann S. 2020. SARSCoV-2 Cell Entry Depends on ACE2 and TMPRSS2 and Is Blocked by a Clinically Proven Protease Inhibitor. Cell 181:271-280.e8.

27. European Medicines Agency. 2021. EMA recommends COVID-19 Vaccine AstraZeneca for authorisation in the EU.

28. European Medicines Agency. 2021. EMA recommends COVID-19 Vaccine Moderna for authorisation in the EU.

29. European Medicines Agency. 2021. EMA recommends COVID-19 Vaccine Comirnaty for authorisation in the EU.

30. Voysey M, Costa Clemens SA, Madhi SA, Weckx LY, Folegatti PM, Aley PK, Angus B, Baillie VL, Barnabas SL, Bhorat QE, Bibi S, Briner C, Cicconi P, Clutterbuck EA, Collins AM, Cutland CL, Darton TC, Dheda K, Dold C, Duncan CJA, Emary KRW, Ewer KJ, Flaxman A, Fairlie L, Faust SN, Feng S, Ferreira DM, Finn A, Galiza E, Goodman AL, Green CM, Green CA, Greenland M, Hill C, Hill HC, Hirsch I, Izu A, Jenkin D, Joe CCD, Kerridge S, Koen A, Kwatra G, Lazarus R, Libri V, Lillie PJ, Marchevsky NG, Marshall RP, Mendes AVA, Milan EP, Minassian AM, McGregor A, Mujadidi YF, Nana A, Padayachee SD, Phillips DJ, Pittella A, Plested E, Pollock KM, Ramasamy MN, Ritchie AJ, Robinson H, Schwarzbold A V., Smith A, Song R, Snape MD, Sprinz E, Sutherland RK, Thomson EC, Török ME, Toshner M, Turner DPJ, Vekemans J, Villafana TL, White T, Williams CJ, Douglas AD, Hill AVS, Lambe T, Gilbert SC, Pollard AJ, Aban M, Abeyskera KWM, Aboagye J, Adam M, Adams K, Adamson JP, Adewatan G, Adlou S, Ahmed K, Akhalwaya Y, Akhalwaya S, Alcock A, Ali A, Allen ER, Allen L, Alvernaz FB, Amorim FS, Andrade CS, Andritsou F, Anslow R, Arbe-Barnes EH, Ariaans MP, Arns B, Arruda L, Assad L, Azi PDA, Azi LDA, Babbage G, Bailey C, Baker KF, Baker M, Baker N, Baker P, Baleanu I, Bandeira D, Bara A, Barbosa MAS, Barker D, Barlow GD, Barnes E, Barr AS, Barrett JR, Barrett J, Barrett K, Bates L, Batten A, Beadon K, Beales E, Beckley R, Belij-Rammerstorfer S, Bell J, Bellamy D, Belton S, Berg A, Bermejo L, Berrie E, Berry L, Berzenyi D, Beveridge A, Bewley KR, Bharaj I, Bhikha S, 
medRxiv preprint doi: https://doi.org/10.1101/2021.05.30.21257971; this version posted July 15, 2021. The copyright holder for this preprint

(which was not certified by peer review) is the author/funder, who has granted medRxiv a license to display the preprint in perpetuity.

All rights reserved. No reuse allowed without permission.

Bhorat AE, Bhorat ZE, Bijker EM, Birch S, Birch G, Birchall K, Bird A, Bird O, Bisnauthsing K, Bittaye M, Blackwell L, Blacow R, Bletchly H, Blundell CL, Blundell SR, Bodalia P, Bolam E, Boland E, Bormans D, Borthwick N, Bowring F, Boyd A, Bradley P, Brenner T, Bridges-Webb A, Brown P, Brown C, Brown-O'Sullivan C, Bruce S, Brunt E, Budd W, Bulbulia YA, Bull M, Burbage J, Burn A, Buttigieg KR, Byard N, Cabrera Puig I, Calvert A, Camara S, Cao M, Cappuccini F, Cardona R, Cardoso JR, Carr M, Carroll MW, Carson-Stevens A, Carvalho Y de M, Casey HR, Cashen P, Castro TRY, Castro LC, Cathie K, Cavey A, Cerbino-Neto J, Cezar LFF, Chadwick J, Chanice C, Chapman D, Charlton S, Cheliotis KS, Chelysheva I, Chester O, Chiplin E, Chita S, Cho JS, Cifuentes L, Clark E, Clark M, Colin-Jones R, Collins SLK, Colton H, Conlon CP, Connarty S, Coombes N, Cooper C, Cooper R, Cornelissen L, Corrah T, Cosgrove CA, Costa FB, Cox T, Crocker WEM, Crosbie S, Cullen D, Cunha DRMF, Cunningham CJ, Cuthbertson FC, da Costa DM, Da Guarda SNF, da Silva LP, da Silva Moraes AC, Damratoski BE, Danos Z, Dantas MTDC, Datoo MS, Datta C, Davids M, Davies SL, Davies K, Davies H, Davies S, Davies J, Davis EJ, Davis J, de Carvalho JAM, De Jager J, de Jesus Jnr S, De Oliveira Kalid LM, Dearlove D, Demissie T, Desai A, Di Marco S, Di Maso C, Dinesh T, Docksey C, Dong T, Donnellan FR, Dos Santos TG, Dos Santos TG, Dos Santos EP, Douglas N, Downing C, Drake J, Drake-Brockman R, Drury R, Du Plessis J, Dunachie SJ, Duncan A, Easom NJW, Edwards M, Edwards NJ, Edwards F, El Muhanna OM, Elias SC, Ellison-Handley B, Elmore MJ, English MR, Esmail A, Essack YM, Farooq M, Fedosyuk S, Felle S, Ferguson S, Ferreira Da Silva C, Field S, Fisher R, Fletcher J, Fofie H, Fok H, Ford KJ, Fothergill R, Fowler J, Fraiman PHA, Francis E, Franco MM, Frater J, Freire MSM, Fry SH, Fudge S, Furlan Filho R, Furze J, Fuskova M, Galian-Rubio P, Garlant H, Gavrila M, Gibbons KA, Gilbride C, Gill H, Godwin K, Gokani K, Gonçalves MLF, Gonzalez IGS, Goodall J, Goodwin J, Goondiwala A, Gordon-Quayle K, Gorini G, Goyanna A, Grab J, Gracie L, Green J, Greenwood N, Greffrath J, Groenewald MM, Gunawardene A, Gupta G, Hackett M, Hallis B, Hamaluba M, Hamilton E, Hamlyn J, Hammersley D, Hanrath AT, Hanumunthadu B, Harris SA, Harris C, Harrison TD, Harrison D, Harris-Wright TA, Hart TC, Hartnell B, Haughney J, Hawkins S, Hayano LYM, Head I, Heath PT, Henry JA, Hermosin Herrera M, Hettle DB, Higa C, Hill J, Hodges G, Hodgson S, Horne E, Hou MM, Houlihan CF, Howe E, Howell N, Humphreys J, Humphries HE, Hurley K, Huson C, Hyams C, Hyder-Wright A, Ikram $\mathrm{S}$, Ishwarbhai A, Iveson P, Iyer V, Jackson F, Jackson S, Jaumdally S, Jeffers H, Jesudason N, Jones C, Jones C, Jones K, Jones E, Jorge MR, Joshi A, Júnior EAMS, Kailath R, Kana F, Kar A, Karampatsas K, Kasanyinga M, Kay L, Keen J, Kellett Wright J, Kelly EJ, Kelly D, Kelly DM, Kelly S, Kerr D, Khan L, Khozoee B, Khurana A, Kidd S, Killen A, Kinch J, Kinch P, King LDW, King TB, Kingham L, Klenerman P, Kluczna DM, Knapper F, Knight JC, Knott D, Koleva S, Lages PM, Lang M, Lang G, Larkworthy CW, Larwood JPJ, Law R, Lawrie AM, Lazarus EM, Leach A, Lees EA, Lelliott A, Lemm NM, Lessa AER, Leung S, Li Y, Lias AM, Liatsikos K, Linder A, Lipworth S, Liu S, Liu X, Lloyd A, Lloyd S, Loew L, Lopez Ramon R, Lora LB, Luz KG, MacDonald JC, MacGregor G, Madhavan M, Mainwaring DO, Makambwa E, Makinson R, Malahleha M, Malamatsho R, Mallett G, Manning N, Mansatta K, Maoko T, Marinou S, Marlow E, Marques GN, Marriott P, Marshall RP, Marshall JL, Masenya M, Masilela M, Masters SK, Mathew M, Matlebjane H, Matshidiso K, Mazur O, Mazzella A, McCaughan H, McEwan J, McGlashan J, McInroy L, McRobert N, McSwiggan S, Megson C, Mehdipour 
medRxiv preprint doi: https://doi.org/10.1101/2021.05.30.21257971; this version posted July 15, 2021. The copyright holder for this preprint (which was not certified by peer review) is the author/funder, who has granted medRxiv a license to display the preprint in perpetuity.

All rights reserved. No reuse allowed without permission.

S, Meijs W, Mendonça RNÕ, Mentzer AJ, Mesquita ACF, Miralhes P, Mirtorabi N, Mitton C, Mnyakeni S, Moghaddas F, Molapo K, Moloi M, Moore M, Moran M, Morey E, Morgans R, Morris SJ, Morris S, Morrison H, Morselli F, Morshead G, Morter R, Mottay L, Moultrie A, Moyo N, Mpelembue M, Msomi S, Mugodi Y, Mukhopadhyay E, Muller J, Munro A, Murphy S, Mweu P, Myerscough C, Naik G, Naker K, Nastouli E, Ndlovu B, Nikolaou E, Njenga C, Noal HC, Noé A, Novaes G, Nugent FL, Nunes GLA, O’Brien K, O’Connor D, Oelofse S, Oguti B, Olchawski V, Oldfield NJ, Oliveira MG, Oliveira C, Oliveira ISQ, Oommen-Jose A, Oosthuizen A, O'Reilly P, O’Reilly PJ, Osborne P, Owen DRJ, Owen L, Owens D, Owino N, Pacurar M, Paiva BVB, Palhares EMF, Palmer S, Parracho HMRT, Parsons K, Patel D, Patel B, Patel F, Patrick-Smith M, Payne RO, Peng Y, Penn EJ, Pennington A, Peralta Alvarez MP, Pereira Stuchi BP, Perez AL, Perinpanathan T, Perring J, Perumal R, Petkar SY, Philip T, Phillips J, Phohu MK, Pickup L, Pieterse S, Pinheiro JM, Piper J, Pipini D, Plank M, Plant S, Pollard S, Pooley J, Pooran A, Poulton I, Powers C, Presa FB, Price DA, Price V, Primeira MR, Proud PC, Provstgaard-Morys S, Pueschel S, Pulido D, Quaid S, Rabara R, Radia K, Rajapaska D, Rajeswaran T, Ramos L, Ramos ASF, Ramos Lopez F, Rampling T, Rand J, Ratcliffe H, Rawlinson T, Rea D, Rees B, Resuello-Dauti M, Reyes Pabon E, Rhead S, Riaz T, Ricamara M, Richards A, Richter A, Ritchie N, Ritchie AJ, Robbins AJ, Roberts H, Robinson RE, Roche S, Rollier C, Rose L, Ross Russell AL, Rossouw L, Royal S, Rudiansyah I, Ryalls K, Sabine C, Saich S, Sale JC, Salman AM, Salvador N, Salvador S, Sampaio MD, Samson AD, Sanchez-Gonzalez A, Sanders H, Sanders K, Santos E, Santos Guerra MFS, Satti I, Saunders JE, Saunders C, Sayed ABA, Schim van der Loeff I, Schmid AB, Schofield E, Screaton GR, Seddiqi S, Segireddy RR, Senger R, Serrano S, Shaik I, Sharpe HR, Sharrocks K, Shaw R, Shea A, Sheehan E, Shepherd A, Shiham F, Silk SE, Silva-Reyes L, Silveira LBTD, Silveira MBV, Singh N, Sinha J, Skelly DT, Smith DC, Smith N, Smith HE, Smith DJ, Smith CC, Soares AS, Solórzano C, Sorio GL, Sorley K, Sosa-Rodriguez T, Souza CMCDL, Souza BSDF, Souza AR, Souza Lopez T, Sowole L, Spencer AJ, Spoors L, Stafford L, Stamford I, Stein R, Stockdale L, Stockwell L V., Strickland LH, Stuart A, Sturdy A, Sutton N, Szigeti A, Tahiri-Alaoui A, Tanner R, Taoushanis C, Tarr AW, Tarrant R, Taylor K, Taylor U, Taylor IJ, Taylor J, te Water Naude R, Templeton K, Themistocleous Y, Themistocleous A, Thomas M, Thomas K, Thomas TM, Thombrayil A, Thompson J, Thompson F, Thompson A, Thompson A, Thompson K, Thornton-Jones V, Thotusi LHS, Tighe PJ, Tinoco LA, Tiongson GF, Tladinyane B, Tomasicchio M, Tomic A, Tonks S, Towner J, Tran N, Tree JA, Trillana G, Trinham C, Trivett R, Truby A, Tsheko BL, Tubb P, Turabi A, Turner R, Turner C, Turner N, Tyagi B, Ulaszewska M, Underwood BR, van Eck S, Varughese R, Verbart D, Verheul MK, Vichos I, Vieira TA, Walker G, Walker L, Wand ME, Wardell T, Warimwe GM, Warren SC, Watkins B, Watson MEE, Watson E, Webb S, Webster A, Welch J, Wellbelove Z, Wells JH, West AJ, White B, White C, White R, Williams P, Williams RL, Willingham S, Winslow R, Woods D, Woodyer M, Worth AT, Wright D, Wroblewska M, Yao A, Yim YTN, Zambrano MB, Zimmer RL, Zizi D, Zuidewind P. 2021. Single-dose administration and the influence of the timing of the booster dose on immunogenicity and efficacy of ChAdOx $1 \mathrm{nCoV}-19$ (AZD1222) vaccine: a pooled analysis of four randomised trials. Lancet 397:881-891.

31. Khoury DS, Cromer D, Reynaldi A, Schlub TE, Wheatley AK, Juno JA, Subbarao K, Kent SJ, Triccas JA, Davenport MP. 2021. Neutralizing antibody levels are highly 
medRxiv preprint doi: https://doi.org/10.1101/2021.05.30.21257971; this version posted July 15, 2021. The copyright holder for this preprint

predictive of immune protection from symptomatic SARS-CoV-2 infection. Nat Med.

32. Sekine T, Perez-Potti A, Rivera-Ballesteros O, Strålin K, Gorin JB, Olsson A, LlewellynLacey S, Kamal H, Bogdanovic G, Muschiol S, Wullimann DJ, Kammann T, Emgård J, Parrot T, Folkesson E, Akber M, Berglin L, Bergsten H, Brighenti S, Brownlie D, Butrym M, Chambers B, Chen P, Jeannin MC, Grip J, Gomez AC, Dillner L, Lozano ID, Dzidic M, Tullberg MF, Färnert A, Glans H, Haroun-Izquierdo A, Henriksson E, Hertwig L, Kalsum S, Kokkinou E, Kvedaraite E, Loreti M, Lourda M, Maleki K, Malmberg KJ, Marquardt N, Maucourant C, Michaelsson J, Mjösberg J, Moll K, Muva J, Mårtensson J, Nauclér P, Norrby-Teglund A, Medina LP, Persson B, Radler L, Ringqvist E, Sandberg JT, Sohlberg E, Soini T, Svensson M, Tynell J, Varnaite R, Kries A Von, Unge C, Rooyackers O, Eriksson LI, Henter JI, Sönnerborg A, Allander T, Albert J, Nielsen M, Klingström J, Gredmark-Russ S, Björkström NK, Sandberg JK, Price DA, Ljunggren HG, Aleman S, Buggert M. 2020. Robust T Cell Immunity in Convalescent Individuals with Asymptomatic or Mild COVID-19. Cell 183:158-168.e14.

33. Rydyznski Moderbacher C, Ramirez SI, Dan JM, Grifoni A, Hastie KM, Weiskopf D, Belanger S, Abbott RK, Kim C, Choi J, Kato Y, Crotty EG, Kim C, Rawlings SA, Mateus J, Tse LPV, Frazier A, Baric R, Peters B, Greenbaum J, Ollmann Saphire E, Smith DM, Sette A, Crotty S. 2020. Antigen-Specific Adaptive Immunity to SARS-CoV-2 in Acute COVID-19 and Associations with Age and Disease Severity. Cell 183:996-1012.e19.

34. Dai L, Gao GF. 2021. Viral targets for vaccines against COVID-19. Nat Rev Immunol 21:73-82.

35. Zhou D, Dejnirattisai W, Supasa P, Liu C, Mentzer AJ, Ginn HM, Zhao Y, Duyvesteyn HME, Tuekprakhon A, Nutalai R, Wang B, Paesen GC, Lopez-Camacho C, Slon-Campos J, Hallis B, Coombes N, Bewley K, Charlton S, Walter TS, Skelly D, Lumley SF, Dold C, Levin R, Dong T, Pollard AJ, Knight JC, Crook D, Lambe T, Clutterbuck E, Bibi S, Flaxman A, Bittaye M, Belij-Rammerstorfer S, Gilbert S, James W, Carroll MW, Klenerman P, Barnes E, Dunachie SJ, Fry EE, Mongkolsapaya J, Ren J, Stuart DI, Screaton GR. 2021. Evidence of escape of SARS-CoV-2 variant B.1.351 from natural and vaccine-induced sera. Cell 184:2348-2361.e6.

36. Madhi SA, Baillie V, Cutland CL, Voysey M, Koen AL, Fairlie L, Padayachee SD, Dheda K, Barnabas SL, Bhorat QE, Briner C, Kwatra G, Ahmed K, Aley P, Bhikha S, Bhiman JN, Bhorat AE, du Plessis J, Esmail A, Groenewald M, Horne E, Hwa S-H, Jose A, Lambe T, Laubscher M, Malahleha M, Masenya M, Masilela M, McKenzie S, Molapo K, Moultrie A, Oelofse S, Patel F, Pillay S, Rhead S, Rodel H, Rossouw L, Taoushanis C, Tegally H, Thombrayil A, van Eck S, Wibmer CK, Durham NM, Kelly EJ, Villafana TL, Gilbert S, Pollard AJ, de Oliveira T, Moore PL, Sigal A, Izu A. 2021. Efficacy of the ChAdOx1 nCoV-19 Covid-19 Vaccine against the B.1.351 Variant. N Engl J Med 384:1885-1898.

37. Liu J, Liu Y, Xia H, Zou J, Weaver SC, Swanson KA, Cai H, Cutler M, Cooper D, Muik A, Jansen KU, Sahin U, Xie X, Dormitzer PR, Shi P. 2021. BNT162b2-elicited neutralization of B.1.617 and other SARS-CoV-2 variants. Nature.

38. Sterlin D, Mathian A, Miyara M, Mohr A, Anna F, Claër L, Quentric P, Fadlallah J, Devilliers H, Ghillani P, Gunn C, Hockett R, Mudumba S, Guihot A, Luyt C-E, Mayaux J, 
medRxiv preprint doi: https://doi.org/10.1101/2021.05.30.21257971; this version posted July 15, 2021. The copyright holder for this preprint

Beurton A, Fourati S, Bruel T, Schwartz O, Lacorte J-M, Yssel H, Parizot C, Dorgham K, Charneau P, Amoura Z, Gorochov G. 2021. IgA dominates the early neutralizing antibody response to SARS-CoV-2. Sci Transl Med 13:eabd2223.

39. Alter G, Yu J, Jinyan L, Borducchi EN, Tostanoski LH, Mcmahan K, Jacob-dolan C, Martinez DR, Chang A, Anioke T, Lifton M, Joseph N, Stephenson E, Krammer F, Baric RS, Gars M Le, Sadoff J, Groot AM De, Cov A. 2021. Immunogenicity of Ad26.COV2.S vaccine against SARS-CoV-2 variants in humans. Nature.

40. Krammer F, Srivastava K, Alshammary H, Amoako AA, Awawda MH, Beach KF, Bermúdez-González MC, Bielak DA, Carreño JM, Chernet RL, Eaker LQ, Ferreri ED, Floda DL, Gleason CR, Hamburger JZ, Jiang K, Kleiner G, Jurczyszak D, Matthews JC, Mendez WA, Nabeel I, Mulder LCF, Raskin AJ, Russo KT, Salimbangon A-BT, Saksena M, Shin AS, Singh G, Sominsky LA, Stadlbauer D, Wajnberg A, Simon V. 2021. Antibody Responses in Seropositive Persons after a Single Dose of SARS-CoV-2 mRNA Vaccine. N Engl J Med 384:1372-1374.

41. Frieman M, Harris AD, Herati RS, Krammer F, Mantovani A, Rescigno M, Sajadi MM, Simon V. 2021. SARS-CoV-2 vaccines for all but a single dose for COVID-19 survivors. EBioMedicine 68:103401.

42. Hoffmann M, Hofmann-Winkler H, Krüger N, Kempf A, Nehlmeier I, Graichen L, Sidarovich A, Moldenhauer A-S, Winkler MS, Schulz S, Jäck H-M, Stankov M V, Behrens GMN, Pöhlmann S. 2021. SARS-CoV-2 variant B.1.617 is resistant to Bamlanivimab and evades antibodies induced by infection and vaccination. bioRxiv 2021.05.04.442663.

43. Kleine-Weber H, Elzayat MT, Hoffmann M, Pöhlmann S. 2018. Functional analysis of potential cleavage sites in the MERS-coronavirus spike protein. Sci Rep 8:16597.

44. Berger Rentsch M, Zimmer G. 2011. A Vesicular Stomatitis Virus Replicon-Based Bioassay for the Rapid and Sensitive Determination of Multi-Species Type I Interferon. PLoS One 6:e25858.

45. Kasturi SP, Rasheed MAU, Havenar-Daughton C, Pham M, Legere T, Sher ZJ, Kovalenkov Y, Gumber S, Huang JY, Gottardo R, Fulp W, Sato A, Sawant S, StanfieldOakley S, Yates N, LaBranche C, Alam SM, Tomaras G, Ferrari G, Montefiori D, Wrammert J, Villinger F, Tomai M, Vasilakos J, Fox CB, Reed SG, Haynes BF, Crotty S, Ahmed R, Pulendran B. 2020. 3M-052, a synthetic TLR-7/8 agonist, induces durable HIV-1 envelope-specific plasma cells and humoral immunity in nonhuman primates. Sci Immunol 5:eabb1025.

46. European Medicines Agency. 2010. Missing data in confirmatory clinical trials.

47. Althaus K, Möller P, Uzun G, Singh A, Beck A, Bettag M, Bösmüller H, Guthoff M, Dorn F, Petzold GC, Henkes H, Heyne N, Jumaa H, Kreiser K, Limpach C, Luz B, Maschke M, Müller JA, Münch J, Nagel S, Pötzsch B, Müller J, Schlegel C, Viardot A, Bäzner H, Wolf M, Pelzl L, Warm V, Willinek WA, Steiner J, Schneiderhan-Marra N, Vollherbst D, Sachs UJ, Fend F, Bakchoul T. 2021. Antibody-mediated procoagulant platelets in SARSCoV-2- vaccination associated immune thrombotic thrombocytopenia. Haematologica. 
medRxiv preprint doi: https://doi.org/10.1101/2021.05.30.21257971; this version posted July 15, 2021. The copyright holder for this preprint

(which was not certified by peer review) is the author/funder, who has granted medRxiv a license to display the preprint in perpetuity.

All rights reserved. No reuse allowed without permission.

\section{Acknowledgments}

We thank all participants for regular blood donations. We thank Nicola Schrott, Regina Burger, Jana Romana Fischer, Birgit Ott, Carolin Ludwig, Katrin Ring, Nadine Pfeifer, Maxine Rustler, Vivien Prex for skillful laboratory assistance. We thank Sarah Warth, Simona Ursu, and Christian Buske of the flow cytometry core facility for support with flow cytometric analysis. We thank the Robert Koch Institute (RKI) for financial support. This project has received funding from the European Union's Horizon 2020 research and innovation programme under grant agreement No 101003555 (Fight-nCoV) to J.M., the German Research Foundation (CRC1279) to F.K. and J.M., the BMBF to F.K. (Restrict SARS-CoV-2) and an individual research grant (to J.A.M.). J.A.M. is indebted to the Baden-Württemberg Stiftung for the financial support of this research project by the Eliteprogramme for Postdocs. R.G., A.S., and C.C. are part of the International Graduate School in Molecular Medicine Ulm. S.P. received funding from BMBF (01KI1723D, 01KI20328A, 01KI20396, 01KX2021) and the county of Lower Saxony (14-76103-184, MWK HZI COVID-19). H.S. acknowledges funding from the Ministry for Science, Research and the Arts of Baden-Württemberg, Germany and the European Commission (HORIZON2020 Project SUPPORT-E, no. 101015756).

\section{Funding}

This project has received funding from the European Union's Horizon 2020 research and innovation programme under grant agreement No 101003555 (Fight-nCoV) to J.M., the German Research Foundation (CRC1279) to F.K. and J.M., the BMBF to F.K. (Restrict SARS-CoV-2) an individual research grant (to J.A.M.), the Robert Koch Institute (RKI), the Baden-Württemberg Stiftung via the Eliteprogramme for Postdocs (to J.A.M.). Additional funding to S.P. from BMBF to (01KI1723D, 01KI20328A, 01KI20396, 01KX2021) and the county of Lower Saxony (1476103-184, MWK HZI COVID-19) and to H.S. from the Ministry for Science, Research and the Arts of Baden-Württemberg, Germany and the European Commission (HORIZON2020 Project SUPPORT-E, no. 101015756).

\section{Author contributions}

Conceptualization, J.A.M., J.M., R.G., M.Z., A.S.; Funding acquisition, J.A.M., J.M., F.K., S.P., H.S.; Investigation, R.G., M. Z., A.S., C.C., A.G., D.K., S.E.E., A.B. J.K.; Essential resources, B.M., M.H., S.P., B.J., H.S., F.K., J.M., J.A.M.; Writing, J.A.M., R.G., M.Z., A.S.; Review and editing, all authors. R.G., M.Z., A.S. contributed equally. R.G., M.Z., A.S. and J.A.M verified the underlying data.

\section{Competing interests}

The authors declare no competing interests.

\section{Data and materials availability}

Raw data is available upon request. 